\title{
Photochemistry and Vibrational Spectroscopy of the Trans and Cis Conformers of Acetic Acid in Solid Ar
}

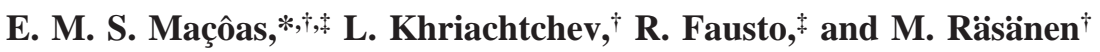 \\ Department of Chemistry, University of Helsinki, P.O. Box 55, FIN-00014 Helsinki, Finland, and \\ Department of Chemistry (CQC), University of Coimbra, P-3004-535 Coimbra, Portugal
}

Received: December 12, 2003; In Final Form: February 9, 2004

\begin{abstract}
Acetic acid monomer has two stable geometries, the cis and trans conformers. The high-energy cis conformer has been recently detected experimentally for the fïst time [Maçôas et al. J. Am. Chem. Soc. 2003, 125, 16188]. The cis conformer can be produced in low-temperature rare-gas matrixes upon vibrational excitation of the ground-state trans conformer. Fast tunneling from cis- to trans-acetic acid takes place even at the lowest working temperatures $(8 \mathrm{~K})$, limiting the time available to study the high-energy form. Deuteration of the hydroxyl group reduces the tunneling rate by approximately 4 orders of magnitude, increasing accordingly the lifetime of the unstable conformer and its available concentration. In this work, we present a detailed analysis of the vibrational spectra of the cis form of four acetic acid isotopologues $\left(\mathrm{CH}_{3} \mathrm{COOH}, \mathrm{CH}_{3} \mathrm{COOD}\right.$, $\mathrm{CD}_{3} \mathrm{COOH}$ and $\left.\mathrm{CD}_{3} \mathrm{COOD}\right)$. Photolysis $(193 \mathrm{~nm})$ of the trans and cis forms of the perdeuterated compound was performed to evaluate the possible conformational dependence of photodissociation of acetic acid. However, no evidence of conformer specific photodissociation was found. The UV photolysis of the matrix-isolated acetic acid reveals very different products from the gas phase. Methanol complexed with carbon monoxide is the major product of photolysis of acetic acid isolated in Ar matrixes whereas it has never been observed as a photolysis product in the gas phase.
\end{abstract}

\section{Introduction}

Acetic acid has two planar conformers, trans and cis, with a computationally predicted energy difference of about $1883 \mathrm{~cm}^{-1}$ in favor of the trans conformer and an energy barrier for the trans to cis isomerization of $4432 \mathrm{~cm}^{-1}{ }^{1}$ The spectroscopic properties and reactivity of the trans conformer have been studied in detail. ${ }^{2-5}$ Nevertheless, despite the fact that acetic acid has been the subject of many experimental and theoretical studies, ${ }^{1-10}$ including studies of conformational equilibrium in the gas phase and aqueous solution, only recently was the cis conformer detected experimentally. ${ }^{11}$ The IR absorption spectra of cis- $\mathrm{CH}_{3} \mathrm{COOH}$ was measured in an Ar matrix after excitation of the $\mathrm{O}-\mathrm{H}$ stretching overtone of trans $-\mathrm{CH}_{3} \mathrm{COOH} .{ }^{11}$ The preparation of cis acetic acid followed the method of selective IR pumping as was earlier applied. ${ }^{12-14}$ The produced cis conformer tunnels back to the trans form in a minute time scale, which greatly limits the time available to study the high-energy conformer. ${ }^{11}$ In that study, to overcome the limitation due to the lifetime of the unstable conformer, the IR absorption spectrum was collected during IR irradiation of trans $-\mathrm{CH}_{3}-$ $\mathrm{COOH}$. Deuteration of the hydroxyl group slows down the tunneling rate, allowing a more accurate study of this species.

Small molecules with more than one conformer may exhibit conformer-selective photochemistry, as shown in the case of UV photolysis of formic acid $(\mathrm{HCOOH})$ in solid argon. ${ }^{15}$ Photochemical excitation, as opposed to thermal excitation, may deposit energy selectively into a molecule, thus inducing specific reaction channels. ${ }^{16}$ Decomposition dynamics of acetic acid has

* To whom correspondence should be addressed. E-mail: emacoas@ qui.uc.pt.

University of Helsinki.

$\doteqdot$ University of Coimbra. been extensively investigated both theoretically and experimentally (see ref 17 for an overview on this subject and references therein). Theoretically, the ground-state decomposition channels of acetic acid were shown to depend on the initial conformational state, ${ }^{18}$ the decarboxylation channel being associated with the cis conformer and the dehydration channel with the trans conformer. Experimentally, thermal decomposition in the gaseous phase occurs mainly via the decarboxylation and dehydration channels in a 1:2 proportion, yielding carbon dioxide with methane and ketene $\left(\mathrm{CH}_{2}=\mathrm{C}=\mathrm{O}\right)$ with water, respectively. ${ }^{19,20}$ The gas-phase photodecomposition of acetic acid was shown to produce mainly acetyl and hydroxyl radicals. ${ }^{21-24}$

The present work has a 2-fold task. First, we study in detail the vibrational spectra of the cis conformer of acetic acid isolated in solid $\mathrm{Ar}$, including three deuterated isotopologues $\left(\mathrm{CH}_{3}-\right.$ $\mathrm{COOD}, \mathrm{CD}_{3} \mathrm{COOH}$, and $\mathrm{CD}_{3} \mathrm{COOD}$ ), with special emphasis on the perdeuterated form. A revised vibrational assignment for the trans conformers is also proposed. Second, we study the photolysis of acetic acid isolated in Ar. Perdeuterated acetic acid was used to evaluate the conformational specificity of the $193 \mathrm{~nm}$ photodecomposition process. The lack of conformer dependent photodecomposition channels is discussed, as well as the influence of solid matrix on the photodecomposition products of acetic acid. ${ }^{25-29}$ The 1:1 complex of methanol with carbon monoxide that is the major product of photolysis in the Ar matrix is identified on the basis of ab initio calculations.

\section{Experimental and Computational Details}

The gaseous samples were prepared by mixing acetic acid (Sigma-Aldrich, $>99 \%$ ) or its isotopologues $\left(\mathrm{CD}_{3} \mathrm{COOD}\right.$ and $\mathrm{CH}_{3} \mathrm{COOD}, 99.5 \%$ ), degassed by several freeze-pump-thaw 
cycles, with high-purity argon (AGA, 99.9999\%), typically in the $1: 2000$ or $1: 1000$ proportions. The $\mathrm{CD}_{3} \mathrm{COOH}$ species was obtained from the fully deuterated species by exchange of deuterium atom of the hydroxyl group with $\mathrm{H}_{2} \mathrm{O}$ adsorbed on the inner surface of the sample container and the deposition line. The $\mathrm{CD}_{3} \mathrm{COOH}$ isotopologue was also present in the $\mathrm{CD}_{3}$ COOD samples as an impurity. The gaseous mixtures were deposited onto a CsI substrate at $15 \mathrm{~K}$ in a closed cycle helium cryostat (APD, DE 202A) and subsequently cooled to $8 \mathrm{~K}$. The IR absorption spectra $\left(7900-400 \mathrm{~cm}^{-1}\right)$ were measured with a Nicolet SX-60 FTIR spectrometer. A liquid nitrogen cooled $\mathrm{MCT}$ detector and a $\mathrm{Ge} / \mathrm{KBr}$ beam splitter were used to record the mid-IR absorption spectra, with spectral resolutions from 0.25 to $1.0 \mathrm{~cm}^{-1}$, and a liquid-nitrogen-cooled $\mathrm{InSb}$ detector and a quartz beam splitter were used for the near-IR absorption spectra, with a spectral resolution of $0.5 \mathrm{~cm}^{-1}$. Typically, 100500 interferograms were co-added.

Tunable pulsed IR radiation provided by an optical parametric oscillator (OPO Sunlite, Continuum, with IR extension) was used to produce cis-acetic acid via vibrational excitation of trans-acetic acid. ${ }^{11}$ The pulse duration was ca. $5 \mathrm{~ns}$, the spectral line width was $\sim 0.1 \mathrm{~cm}^{-1}$, and the repetition rate was $10 \mathrm{~Hz}$. The pulse energy of the OPO in the $7000-5000 \mathrm{~cm}^{-1}$ spectral region is $\sim 0.5 \mathrm{~mJ}$. The Burleigh WA- 4500 wavemeter was used to control the OPO radiation frequency, providing an absolute accuracy better than $1 \mathrm{~cm}^{-1}$. Whenever necessary, the IR absorption spectra were collected during pumping to compensate for the cis to trans tunneling process. The pumping beam was quasi-collinear with the spectrometer beam, and an interference filter transmitting in the $3300-1100 \mathrm{~cm}^{-1}$ region was attached to the detector to prevent its exposure to the pumping radiation. The photodissociation was induced with $193 \mathrm{~nm}$ radiation of an excimer laser (MPB, MSX-250) operating at 1-3 Hz with a typical pulse energy of $16 \mathrm{~mJ}$. The UV irradiation of the trans conformer produces conversion to the cis conformer and vice versa. IR pumping of the UV-produced conformer was undertaken during UV irradiation to convert this conformer back into the conformer under study.

The ab initio calculations were performed using the GAUSSIAN98 package of programs. ${ }^{30}$ The vibrational spectra of the cis and trans forms of various acetic acid isotopologues were calculated at the MP2/6-311++G(2d,2p) level. The ab initio Cartesian harmonic force constants obtained were later used in the normal coordinate analysis. The stable geometries, counterpoise-corrected interaction energies, and vibrational spectra of the complexes of methanol and carbon monoxide were evaluated at the same level of theory. ${ }^{31}$

\section{Results and Discussion}

Vibrational Assignment. For all studied isotopologues, acetic acid adopts exclusively the trans geometry in the as-deposited (nonirradiated) Ar matrix. To excite the acetic acid monomer at energies above the internal rotation barrier, we have used the overtone of the $\mathrm{OH}(\mathrm{D})$ stretching of the trans-conformer, observed at $6957.9,6958.4,5169.5$, and $5167.8 \mathrm{~cm}^{-1}$ for $\mathrm{CH}_{3}$ $\mathrm{COOH}, \mathrm{CD}_{3} \mathrm{COOH}, \mathrm{CH}_{3} \mathrm{COOD}$, and $\mathrm{CD}_{3} \mathrm{COOD}$, respectively. Excitation of this mode using a narrowband IR source promotes the conversion from the trans conformer to the cis form, as reported for a number of other carboxylic acids. ${ }^{32}$ Figure 1 shows the spectrum obtained as a difference between the IR absorption spectra measured after and before the IR pumping of $\mathrm{CH}_{3} \mathrm{COOH}$ and $\mathrm{CD}_{3} \mathrm{COOD}$. The bands pointing upward correspond to cis-acetic acid and the bands pointing downward correspond to the trans conformer. The spectral assignments

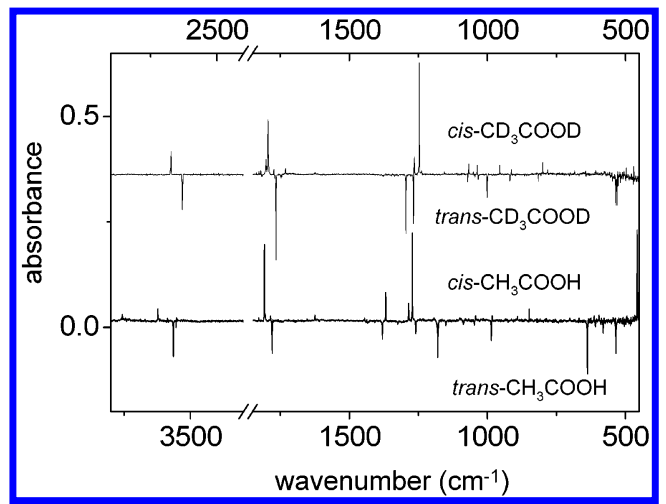

Figure 1. Difference IR absorption spectra showing the formation of cis-acetic acid $\left(\mathrm{CH}_{3} \mathrm{COOH}\right.$ and $\left.\mathrm{CD}_{3} \mathrm{COOD}\right)$ as a result of excitation of the $2 \nu \mathrm{OH}(\mathrm{D})$ modes of the trans conformer.

here presented are based on the calculated ab initio harmonic vibrational frequencies and normal coordinate analysis of acetic acid monomer. The experimental and calculated frequencies and normalized intensities as well as the potential energy distribution for the cis and trans conformers of $\mathrm{CH}_{3} \mathrm{COOH}$ and $\mathrm{CD}_{3} \mathrm{COOD}$ are presented in Tables 1 and 2. The data for $\mathrm{CH}_{3} \mathrm{COOD}$ and $\mathrm{CD}_{3} \mathrm{COOH}$ can be found in the Supporting Information (Tables $\mathrm{S} 1$ and $\mathrm{S} 2$ ).

Assignment for the Trans Conformer. In general, the PEDs calculated for the trans conformers agree with those reported earlier. ${ }^{6}$ Several studies have been previously dedicated to the analysis of the IR absorption spectra of the trans-acetic acid in the gas phase and isolated in Ar matrixes. ${ }^{2-5}$ In our work, we could not observe the $\mathrm{CH}(\mathrm{D})_{3}$ stretching modes for any of the isotopologues studied, which agrees with their very low calculated intensity (see Tables 1 and 2). For the absorptions from 3600 to $1250 \mathrm{~cm}^{-1}$ (OH(D), $\mathrm{CH}(\mathrm{D})_{3}, \mathrm{C}=\mathrm{O}$, and $\mathrm{C}-\mathrm{O}$ stretches) our analysis supports the previous assignments. The discrepancy concerns the assignment of the $\mathrm{COH}$ bending mode $(\delta(\mathrm{COH}))$ made previously. ${ }^{5}$ In that paper, an increase of the $\delta(\mathrm{COH})$ frequency upon deuteration was claimed. The $\delta(\mathrm{COH})$ modes of trans $-\mathrm{CH}_{3} \mathrm{COOH}$ and trans- $\mathrm{CD}_{3} \mathrm{COOH}$ were assigned to the bands at 1181 and $1208 \mathrm{~cm}^{-1}$, respectively, whereas the $\delta(\mathrm{COD})$ modes for trans- $\mathrm{CH}_{3} \mathrm{COOD}$ and trans- $\mathrm{CD}_{3} \mathrm{COOD}$ were assigned to the bands at 1267 and $1268 \mathrm{~cm}^{-1}$, respectively. We suggest a different assignment of the $\delta(\mathrm{COD})$ modes. On the basis of our calculations, the $\delta(\mathrm{COH})$ modes are close to 1200 $\mathrm{cm}^{-1}$ for trans- $\mathrm{CH}_{3} \mathrm{COOH}$ and trans $-\mathrm{CD}_{3} \mathrm{COOH}$ (assigned to the observed bands at 1179.8 and $1207.2 \mathrm{~cm}^{-1}$, respectively), and for trans $-\mathrm{CH}_{3} \mathrm{COOD}$ and trans- $\mathrm{CD}_{3} \mathrm{COOD}$ the $\delta(\mathrm{COD})$ modes should be red shifted by more than $200 \mathrm{~cm}^{-1}$ from the $\delta(\mathrm{COH})$ bands. This is a normal red shift for the $\delta(\mathrm{COH}(\mathrm{D}))$ mode, expected upon deuteration of the hydroxyl group. Therefore, in agreement with the theoretical predictions, we assign the bands observed at 955.4 and $1000.9 \mathrm{~cm}^{-1}$ to this vibration for trans $-\mathrm{CH}_{3} \mathrm{COOD}$ and trans- $\mathrm{CD}_{3} \mathrm{COOD}$, respectively. These bands had been previously assigned to different $\mathrm{CH}(\mathrm{D})_{3}$ deformation modes. ${ }^{5}$ The comparison between observed and calculated intensities gives further support to the present revised assignment. For trans- $\mathrm{CD}_{3} \mathrm{COOD}$, the $\delta(\mathrm{COD})$ mode is expected to be located between the $\mathrm{CD}_{3}$ bending modes $\left(\delta\left(\mathrm{CD}_{3}\right)\right)$ and the $\mathrm{CD}_{3}$ rocking modes $\left(\gamma\left(\mathrm{CD}_{3}\right)\right)$ and to have an intensity higher than all those vibrations (see Table 2). Accordingly, the band at $1000.9 \mathrm{~cm}^{-1}$ is located between the $\mathrm{CD}_{3}$ angular deformation modes, being the highest intensity band in the 1100 to $800 \mathrm{~cm}^{-1}$ region. For trans $-\mathrm{CH}_{3} \mathrm{COOD}$, the $\delta(\mathrm{COD})$ had been assigned to a band at $1267 \mathrm{~cm}^{-1}, 5$ which we reassign now to the $v(\mathrm{C}-\mathrm{O})$ vibration. The $v(\mathrm{C}-\mathrm{O})$ mode was previ- 


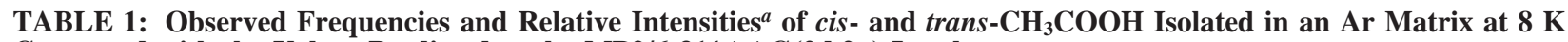
Compared with the Values Predicted at the MP2/6-311++G(2d,2p) Level ${ }^{a}$

\begin{tabular}{|c|c|c|c|c|c|c|c|c|}
\hline assignment (PED) & & $\nu_{\text {calc }}^{\text {trans }}$ & $\nu_{\mathrm{obs}}^{\text {trans }}$ & assignment (PED) & $\nu_{\text {calc }}^{\text {cis }}$ & $v_{\mathrm{obs}}^{\mathrm{cis}}$ & $\Delta v_{\text {calc }}^{\text {cis-trans }}$ & $\Delta v_{\text {obs }}^{\text {cis-trans }}$ \\
\hline$v(\mathrm{OH})(98)$ & $a^{\prime}$ & $3793.6^{(20.9)}$ & $3563.8^{(42.4)}$ & $v(\mathrm{OH})(99)$ & $3859.5^{(17.1)}$ & $3622.6^{(8.4)}$ & +65.9 & +58.8 \\
\hline$v\left(\mathrm{HCH}_{2}\right)$ s. $(100)$ & $a^{\prime}$ & $3236.9^{(0.6)}$ & $3051^{b}$ & $v\left(\mathrm{HCH}_{2}\right)$ s. $(97)$ & $3229.7^{(0.5)}$ & & -7.2 & \\
\hline$v\left(\mathrm{HCH}_{2}\right)$ as. $(100)$ & $a^{\prime \prime}$ & $3196.0^{(0.5)}$ & $2996^{b}$ & $v\left(\mathrm{HCH}_{2}\right)$ as. $(100)$ & $3178.0^{(0.9)}$ & & -18.0 & \\
\hline$v\left(\mathrm{CH}_{3}\right)(98)$ & $a^{\prime}$ & $3115.3^{(0.3)}$ & $2944^{b}$ & $\begin{array}{l}v\left(\mathrm{CH}_{3}\right)(96) \\
\delta\left(\mathrm{CH}_{3}\right)+\tau(\mathrm{C}-\mathrm{O})^{c}\end{array}$ & $3099.4^{(0.9)}$ & $1828.2^{(3.8)}$ & -15.9 & \\
\hline$v(\mathrm{C}=\mathrm{O})(80)$ & $a^{\prime}$ & $1805.2^{(77.8)}$ & $1779.0^{(91.0)}$ & $v(\mathrm{C}=\mathrm{O})(82)$ & $1832.6^{(66.3)}$ & $\begin{array}{l}1807.4^{(94.3)} \\
1784.8^{(5.7)}\end{array}$ & +27.4 & +28.4 \\
\hline$\delta\left(\mathrm{HCH}_{2}\right)$ as. (89) & $a^{\prime \prime}$ & $1506.3^{(2.3)}$ & $1438.8^{(1.8)}$ & $\delta\left(\mathrm{HCH}_{2}\right)$ as. $(91)$ & $1514.3^{(2.1)}$ & $1448.3^{(1.3)}$ & +8.0 & +9.5 \\
\hline$\delta\left(\mathrm{HCH}_{2}\right)$ s. $(90)$ & $a^{\prime}$ & $1501.0^{(4.3)}$ & $1433.6^{(4.1)}$ & $\delta\left(\mathrm{HCH}_{2}\right)$ s. $(92)$ & $1501.2^{(2.0)}$ & $1444.5^{(2.7)}$ & +0.2 & +10.9 \\
\hline$\delta\left(\mathrm{CH}_{3}\right)(82)$ & $a^{\prime}$ & $1434.5^{(14.1)}$ & $\begin{array}{l}1379.4^{(23.3)} \\
1324.4^{(3.2)}\end{array}$ & $\delta\left(\mathrm{CH}_{3}\right)(96)$ & $1421.5^{(12.8)}$ & $1368.3^{(29.0)}$ & -13.0 & -11.1 \\
\hline $\begin{array}{l}v(\mathrm{C}-\mathrm{O})(25)+\delta(\mathrm{COH})(29)+ \\
\quad \delta\left(\mathrm{CH}_{3}\right)(19)\end{array}$ & $a^{\prime}$ & $1352.7^{(10.4)}$ & $1259.4^{(20.8)}$ & $\begin{array}{l}\nu(\mathrm{C}-\mathrm{C})+\tau(\mathrm{C}-\mathrm{O})^{c} \\
v(\mathrm{C}-\mathrm{O})(24)+\delta(\mathrm{COH})(32)+ \\
\quad \gamma\left(\mathrm{CH}_{3}\right) \text { s. }(18)\end{array}$ & $1218.4^{(1.5)}$ & $\begin{array}{l}\mathrm{FR} 1285.4^{(21.2)} \\
1192.9^{(3.0)}\end{array}$ & -134.3 & -66.5 \\
\hline $\begin{array}{l}\delta(\mathrm{COH})(47)+\gamma\left(\mathrm{CH}_{3}\right) \text { s. }(16)+ \\
\quad v(\mathrm{C}-\mathrm{O})(12)\end{array}$ & $a^{\prime}$ & $1210.4^{(56.7)}$ & $1179.8^{(82.0)}$ & $\begin{array}{l}\delta(\mathrm{COH})(55)+v(\mathrm{C}-\mathrm{O})(14)+ \\
\quad v(\mathrm{C}-\mathrm{C})(12)\end{array}$ & $1309.5^{(100.0)}$ & ${ }^{\mathrm{FR}} 1271.9^{(100.0)}$ & +99.1 & +92.1 \\
\hline$\tau(\mathrm{C}-\mathrm{O})+\gamma(\mathrm{C}=\mathrm{O})^{b}$ & & & $1150.4^{(7.6)}$ & & & & & \\
\hline$\gamma\left(\mathrm{CH}_{3}\right)$ a. $(70)+\gamma(\mathrm{C}=\mathrm{O})(21)$ & $a^{\prime}$ & $1084.6^{(1.4)}$ & $1047.2^{(5.5)}$ & $\gamma\left(\mathrm{CH}_{3}\right)$ a. $(70)+\gamma \mathrm{C}=\mathrm{O}(20)$ & $1078.7^{(0.9)}$ & $1042.4^{(6.5)}$ & -5.9 & -4.8 \\
\hline$\gamma\left(\mathrm{CH}_{3}\right)$ s. $(61)+v(\mathrm{C}-\mathrm{O})(20)$ & $a^{\prime \prime}$ & $1011.7^{(21.4)}$ & $985.5^{(24.7)}$ & $\begin{array}{l}\gamma\left(\mathrm{CH}_{3}\right) \mathrm{s} .(61)+v(\mathrm{C}-\mathrm{O})(20) \\
2 \tau(\mathrm{C}-\mathrm{O})^{c}\end{array}$ & $1002.9^{(2.9)}$ & $\begin{array}{l}982.2^{(5.3)} \\
890.5^{(4.1)}\end{array}$ & -8.8 & -3.3 \\
\hline$v(\mathrm{C}-\mathrm{C})(58)+v(\mathrm{C}-\mathrm{O})(37)$ & $a^{\prime}$ & $871.8^{(2.1)}$ & & $v(\mathrm{C}-\mathrm{C})(53)+v(\mathrm{C}-\mathrm{O})(38)$ & $864.9^{(10.8)}$ & $848.6^{(8.0)}$ & & \\
\hline$\tau(\mathrm{C}-\mathrm{O})(77)+\gamma(\mathrm{C}=\mathrm{O})(15)$ & $a^{\prime \prime}$ & $663.4^{(23.9)}$ & $637.8^{(74.7)}$ & $\tau(\mathrm{C}-\mathrm{O})(79)+\gamma(\mathrm{C}=\mathrm{O})(20)$ & $468.2^{(27.2)}$ & $458.0^{(95.9)}$ & -195.2 & -179.8 \\
\hline$\delta(\mathrm{OCO})(85)$ & $a^{\prime}$ & $586.3^{(9.7)}$ & $580.4^{(16.0)}$ & $\delta(\mathrm{OCO})(86)+v(\mathrm{C}-\mathrm{C})(11)$ & $600.7^{(2.0)}$ & & +14.4 & \\
\hline $\begin{array}{l}\gamma(\mathrm{C}=\mathrm{O})(69)+\tau(\mathrm{C}-\mathrm{O})(23)+ \\
\quad \gamma\left(\mathrm{CH}_{3}\right) \text { a. }(15)\end{array}$ & $a^{\prime \prime}$ & $553.1^{(8.5)}$ & $534.2^{(38.5)}$ & $\begin{array}{l}\gamma(\mathrm{C}=\mathrm{O})(63)+\tau(\mathrm{C}-\mathrm{O})(19)+ \\
\quad \gamma\left(\mathrm{CH}_{3}\right) \text { a. }(18)\end{array}$ & $605.2^{(0.4)}$ & & +52.1 & \\
\hline$\delta(\mathrm{CC}=\mathrm{O})(86)$ & $a^{\prime}$ & $427.0^{(1.1)}$ & $428^{b}$ & $\delta(\mathrm{CC}=\mathrm{O})(84)+\gamma\left(\mathrm{CH}_{3}\right) \mathrm{s} .(10)$ & $436.0^{(1.0)}$ & & +9.0 & \\
\hline$\tau\left(\mathrm{CH}_{3}\right)(97)$ & $a^{\prime \prime}$ & $80.2^{(0.06)}$ & & $\tau\left(\mathrm{CH}_{3}\right)(98)$ & $95.2^{(0.3)}$ & & +15 & \\
\hline
\end{tabular}

${ }^{a}$ The observed and calculated intensities were normalized by the intensity of the strongest band of both cis and trans conformers. The normalized values are shown in parentheses. The calculated potential energy distributions on the basis of the ab initio harmonic force constant are also shown. ${ }^{b}$ From ref 5. ${ }^{c}$ Tentative assignment. Symbols: $v$ - stretching; $\delta$ - bending; $\gamma$-rocking; $\tau$-torsion; FR- involved in Fermi resonance.

ously assigned to a band at $1271 \mathrm{~cm}^{-1}$ that is very weak in our spectra and it is most probably due to matrix site effects. ${ }^{5}$ On the other hand, for trans- $\mathrm{CD}_{3} \mathrm{COOD}$, the $v(\mathrm{C}-\mathrm{O})$ and $\delta(\mathrm{COD})$ modes were previously assigned to the bands at 1296 and 1268 $\mathrm{cm}^{-1}, 5$ and they are observed in our spectra at 1294.5 and 1267.5 $\mathrm{cm}^{-1}$, respectively. Those are strong bands probably caused by coupling of $v(\mathrm{C}-\mathrm{O})$ with a non fundamental mode (see Table 2).

Another discrepancy with the assignments made in ref 5 concerns the $\mathrm{COH}$ torsion $(\tau(\mathrm{C}-\mathrm{O}))$ and $\mathrm{C}=\mathrm{O}$ rocking modes $\left(\gamma(\mathrm{C}=\mathrm{O})\right.$ in this work and simply $\gamma$ in ref 5) of trans- $\mathrm{CH}_{3}-$ $\mathrm{COOH}$ and $-\mathrm{CD}_{3} \mathrm{COOH}$. These two $\mathrm{A}^{\prime \prime}$ modes are expected in the $700-500 \mathrm{~cm}^{-1}$ region. In the present work, the $\tau(\mathrm{C}-\mathrm{O})$ modes are assigned to the higher frequency and stronger bands observed in this region (637.8 and $609.0 \mathrm{~cm}^{-1}$ for $\mathrm{CH}_{3} \mathrm{COOH}$ and $\mathrm{CD}_{3} \mathrm{COOH}$, respectively) (see Table 1). This mode is also observed above $600 \mathrm{~cm}^{-1}$ (at $635.4 \mathrm{~cm}^{-1}$ ) for trans-formic acid in solid Ar. ${ }^{13,14}$ The $\gamma(\mathrm{C}=\mathrm{O})$ mode of $\mathrm{CH}_{3} \mathrm{COOH}$ is here assigned to the band observed at lower frequencies $\left(534.2 \mathrm{~cm}^{-1}\right)$. For $\mathrm{CD}_{3} \mathrm{COOH}$, this mode was not observed due to its low intensity but we believe it should be assigned to the band at $479 \mathrm{~cm}^{-1}$ reported previously. ${ }^{5}$ Our assignment for the $\tau(\mathrm{C}-\mathrm{O})$ and $\gamma(\mathrm{C}=\mathrm{O})$ modes is in the reverse order with respect to the literature data. ${ }^{1,2,5}$ The present assignment is based on our ab initio calculations, and it respects the predicted relative position and intensities of the bands originated by the 3 modes absorbing in the $700-500 \mathrm{~cm}^{-1}$ region (see Table 1 ), and it is also supported by previously reported results on normal coordinate analysis. ${ }^{6}$

Assignment for the Cis Conformer. The spectral assignment for the cis conformers is quite straightforward based on the $a b$ initio spectra. The $v(\mathrm{OH}(\mathrm{D}))$ mode of cis-acetic acid is blue shifted by $40-60 \mathrm{~cm}^{-1}$ from the corresponding mode of the trans conformers, in good agreement with the ab initio predic- tions for acetic acid and also with the observed analogous shift of formic acid $\left(\approx 60 \mathrm{~cm}^{-1}\right) \cdot{ }^{13,14}$ The $v(\mathrm{C}=\mathrm{O})$ mode appears also $20-30 \mathrm{~cm}^{-1}$ shifted to higher wavenumbers in the cis conformers as compared with the trans conformers (see Tables 1 and 2 ). The methyl stretching modes, predicted with very low intensities in the $3300-3000 \mathrm{~cm}^{-1}$ and $2400-2200 \mathrm{~cm}^{-1}$ spectral regions for $\mathrm{CH}_{3} \mathrm{COOH}$ and $\mathrm{CD}_{3} \mathrm{COOD}$, respectively, were not observed experimentally.

For $\mathrm{CH}_{3} \mathrm{COOH}$, the $v(\mathrm{C}-\mathrm{O})$ and $\delta(\mathrm{COH})$ vibrations are strongly coupled and perhaps they can be better defined as the $\mathrm{COH}-\mathrm{CO}$ deformation modes, similarly to formic acid. ${ }^{13,14}$ According to the calculations, the mode with the highest contribution from the $\delta(\mathrm{COH})$ coordinate of $c i s-\mathrm{CH}_{3} \mathrm{COOH}$ $\left(1309.5 \mathrm{~cm}^{-1}\right)$ is blue shifted by almost $100 \mathrm{~cm}^{-1}$ from the corresponding mode of the trans conformer $\left(1210.4 \mathrm{~cm}^{-1}\right)$. In contrast, for cis- $\mathrm{CH}_{3} \mathrm{COOH}$ a mode with nearly the same contribution from the $v(\mathrm{C}-\mathrm{O})$ and $\delta(\mathrm{COH})$ coordinates $(1218.4$ $\left.\mathrm{cm}^{-1}\right)$ is predicted to be red shifted by more than $100 \mathrm{~cm}^{-1}$ from the corresponding mode of trans $\left(1352.7 \mathrm{~cm}^{-1}\right)$. For both conformers, the $\delta(\mathrm{COH})$ mode is predicted to be the most intense vibration in the $1400-1200 \mathrm{~cm}^{-1}$ region. For cis $-\mathrm{CD}_{3}$ COOD, the $v(\mathrm{C}-\mathrm{O})$ and $\delta(\mathrm{COD})$ modes are not coupled significantly and the assignments presented in Table 2 agree with both the computational band positions and intensities.

The $\mathrm{C}-\mathrm{C}$ stretching modes $(\nu(\mathrm{C}-\mathrm{C}))$ are observed for the cis conformers in the $850-800 \mathrm{~cm}^{-1}$ region. These modes are predicted to be much more intense in the cis form than in the trans conformer. Below $800 \mathrm{~cm}^{-1}$ our analysis is limited by the relatively low concentration of the cis form. Therefore, we could only detect strong modes for $\mathrm{cis}-\mathrm{CH}_{3} \mathrm{COOH}$ like the $\tau(\mathrm{C}-\mathrm{O})$ fundamental. This mode absorbs at $458.0 \mathrm{~cm}^{-1}$, red shifted by $180 \mathrm{~cm}^{-1}$ from the corresponding band of trans$\mathrm{CH}_{3} \mathrm{COOH}$, which agrees with the $195 \mathrm{~cm}^{-1}$ shift predicted by the ab initio calculations. A band observed at $890.5 \mathrm{~cm}^{-1}$ is 
TABLE 2: Observed Frequencies and Relative Intensities ${ }^{a}$ of cis- and trans-CD $_{3}$ COOD Isolated in an Ar Matrix at 8 K Compared with the Values Predicted at the MP2/6-311++G(2d,2p) Level

\begin{tabular}{|c|c|c|c|c|c|c|c|c|}
\hline assignment (PED) & & $\nu_{\text {calc }}^{\text {trans }}$ & $v_{\mathrm{obs}}^{\text {trans }}$ & assignment (PED) & $\nu_{\text {calc }}^{\text {cis }}$ & $v_{\mathrm{obs}}^{\mathrm{cis}}$ & $\Delta v_{\text {calc }}^{\text {cis }- \text { trans }}$ & $\Delta v_{\mathrm{obs}}^{\mathrm{cis}-\mathrm{trans}}$ \\
\hline$v(\mathrm{OD})(99)$ & $\mathrm{A}^{\prime}$ & $2759.3^{(16.1)}$ & $\begin{array}{l}2630.4^{(27.7)} \\
2629^{(26.5)}\end{array}$ & $v(\mathrm{OD})(99)$ & $2809.9^{(13.4)}$ & $\begin{array}{l}2675.5^{(9.4)} \\
2672.9^{(21.2)}\end{array}$ & +50.6 & +42.5 \\
\hline$v\left(\mathrm{DCD}_{2}\right) \mathrm{s} .(99)$ & $A^{\prime}$ & $2401.2^{(0.4)}$ & $2275^{b}$ & $v\left(\mathrm{DCD}_{2}\right)$ s. $(98)$ & $2394.1^{(0.2)}$ & & -7.1 & \\
\hline$v\left(\mathrm{DCD}_{2}\right)$ as. $(100)$ & $A^{\prime \prime}$ & $2365.2^{(0.3)}$ & $2240^{b}$ & $v\left(\mathrm{DCD}_{2}\right)$ as. $(100)$ & $2352.5^{(0.6)}$ & & -12.7 & \\
\hline$v\left(\mathrm{CD}_{3}\right)(98)$ & $A^{\prime}$ & $2239.2^{(<0.1)}$ & $2116^{b}$ & $v\left(\mathrm{CD}_{3}\right)(98)$ & $2228.4^{(0.3)}$ & $1863.8^{(3.2)}$ & -10.8 & \\
\hline$v(\mathrm{C}=\mathrm{O})(85)$ & $A^{\prime}$ & $1792.1^{(94.0)}$ & $\begin{array}{l}1769.8^{(6.4)} \\
1765.0^{(80.7)} \\
1746.8^{(4.5)} \\
1743.7^{(3.5)}\end{array}$ & $v(\mathrm{C}=\mathrm{O})(86)$ & $1821.6^{(89.4)}$ & $\begin{array}{l}1801^{(31.9)} \\
1794.4^{(96.4)} \\
1730.3^{(6.1)}\end{array}$ & +29.5 & +29.4 \\
\hline & & & $1376.4^{(2.4)}$ & & & $\begin{aligned} & 1367.7^{(1.9)} \\
& \text { FR } 1264.6^{(15.6)}\end{aligned}$ & & \\
\hline$v(\mathrm{C}-\mathrm{O})(43)+v(\mathrm{C}-\mathrm{C})(31)$ & $A^{\prime}$ & $1319.2^{(75.9)}$ & $\mathrm{FR} 1294.5^{(54.4)}$ & $\begin{array}{l}v(\mathrm{C}-\mathrm{O})(39)+v(\mathrm{C}-\mathrm{C})(30)+ \\
\quad \delta(\mathrm{CD})(10)\end{array}$ & $1280.5^{(100.0)}$ & FR $1246.2^{(100.0)}$ & -38.7 & -34.8 \\
\hline $\begin{array}{l}\delta\left(\mathrm{CD}_{3}\right)(63)+\delta\left(\mathrm{DCD}_{2}\right) \mathrm{s} .(16)+ \\
\quad v(\mathrm{C}-\mathrm{O})(14)\end{array}$ & $A^{\prime}$ & $1106.1^{(4.4)}$ & $\begin{array}{l}\text { FR } 1267.5^{(49.2)} \\
1071.3^{(8.2)}\end{array}$ & $\begin{array}{l}\delta\left(\mathrm{CD}_{3}\right)(61)+\delta\left(\mathrm{DCD}_{2}\right) \mathrm{s} .(20)+ \\
\quad v(\mathrm{C}-\mathrm{O})(11)\end{array}$ & $1100.6^{(8.1)}$ & $\begin{array}{l}1238.1^{(5.7)} \\
1066.9^{(8.5)}\end{array}$ & -5.5 & -4.4 \\
\hline$\delta\left(\mathrm{DCD}_{2}\right)$ a. $(91)$ & $\mathrm{A}^{\prime \prime}$ & $1084.9^{(1.1)}$ & $1044.8^{(1.8)}$ & $\delta\left(\mathrm{DCD}_{2}\right)$ a. $(94)$ & $1090.2^{(1.1)}$ & $1050.5^{(2.3)}$ & +5.3 & +5.7 \\
\hline$\delta\left(\mathrm{DCD}_{2}\right) \mathrm{s} .(81)+\delta\left(\mathrm{CD}_{3}\right)(15)$ & $\mathrm{A}^{\prime}$ & $1072.4^{(6.3)}$ & $1033.2^{(4.9)}$ & $\delta\left(\mathrm{DCD}_{2}\right)$ s. $(78)+\delta\left(\mathrm{CD}_{3}\right)(18)$ & $1073.4^{(8.8)}$ & $1036.5^{(9.7)}$ & +1.0 & +3.3 \\
\hline$\delta(\mathrm{COD})(62)+\delta(\mathrm{OCO})(12)$ & $A^{\prime}$ & $1019.1^{(22.7)}$ & $1000.9^{(22.1)}$ & $\delta(\mathrm{COD})(58)+\gamma\left(\mathrm{CD}_{3}\right) \mathrm{s}$. & $973.5^{(5.9)}$ & $954.6^{(5.7)}$ & -45.6 & -56.3 \\
\hline$\gamma\left(\mathrm{CD}_{3}\right)$ a. $(51)+\gamma(\mathrm{C}=\mathrm{O})(42)$ & $A^{\prime \prime}$ & $940.7^{(2.2)}$ & $917.9^{(8.6)}$ & $\gamma\left(\mathrm{CD}_{3}\right)$ a. $(52)+\gamma(\mathrm{C}=\mathrm{O})(40)$ & $933.3^{(1.4)}$ & $913.1^{(4.4)}$ & -7.4 & -4.8 \\
\hline$\gamma\left(\mathrm{CD}_{3}\right)$ s. $(65)+v(\mathrm{C}-\mathrm{O})(22)$ & $A^{\prime}$ & $832.8^{(8.4)}$ & $815.7^{(6.4)}$ & $\begin{array}{l}\gamma\left(\mathrm{CD}_{3}\right) \text { s. }(40)+\delta(\mathrm{COD})(23)+ \\
\quad v(\mathrm{C}-\mathrm{C})(23)\end{array}$ & $795.2^{(1.7)}$ & & -37.6 & \\
\hline $\begin{array}{c}v(\mathrm{C}-\mathrm{C})(54)+\delta(\mathrm{COD})(18)+ \\
v(\mathrm{C}-\mathrm{O})(14)+\delta\left(\mathrm{CD}_{3}\right)(11)\end{array}$ & $\mathrm{A}^{\prime}$ & $768.5^{(0.9)}$ & & $\begin{array}{l}v(\mathrm{C}-\mathrm{C})(27)+v(\mathrm{C}-\mathrm{O})(40)+ \\
\quad \gamma\left(\mathrm{CD}_{3}\right) \text { s. }(17)\end{array}$ & $813.8^{(9.1)}$ & $799.3^{(9.4)}$ & -19.0 & \\
\hline $\begin{array}{l}\gamma(\mathrm{C}=\mathrm{O})(28)+\gamma\left(\mathrm{CD}_{3}\right) \text { a. }(32)+ \\
\quad \tau(\mathrm{C}-\mathrm{O})(41)\end{array}$ & $\mathrm{A}^{\prime \prime}$ & $550.6^{(9.7)}$ & $534.7^{(27.0)}$ & $\gamma(\mathrm{C}=\mathrm{O})(55)+\gamma\left(\mathrm{CD}_{3}\right)$ a. $(39)$ & $516.4^{(2.1)}$ & & -34.2 & \\
\hline$\delta(\mathrm{OCO})(75)+\delta(\mathrm{COD})(13)$ & $\mathrm{A}^{\prime}$ & $536.4^{(12.4)}$ & $530.3^{(24.5)}$ & $\delta(\mathrm{OCO})(76)+v(\mathrm{C}-\mathrm{C})(14)$ & $565.3^{(0.2)}$ & & +28.2 & \\
\hline$\tau(\mathrm{C}-\mathrm{O})(58)+\gamma(\mathrm{C}=\mathrm{O})(34)$ & $A^{\prime \prime}$ & $421.7^{(12.1)}$ & & $\tau(\mathrm{C}-\mathrm{O})(89)+\gamma(\mathrm{C}=\mathrm{O})(10)$ & $352.0^{(1.5)}$ & & -69.7 & \\
\hline$\delta(\mathrm{CC}=\mathrm{O})(76)+\gamma\left(\mathrm{CD}_{3}\right) \mathrm{s} .(18)$ & $\mathrm{A}^{\prime}$ & $375.5^{(1.0)}$ & & $\delta(\mathrm{CC}=\mathrm{O})(75)+\gamma\left(\mathrm{CD}_{3}\right) \mathrm{s} .(18)$ & $377.7^{(17.3)}$ & $382.3^{(50.6)}$ & +2.2 & \\
\hline$\tau\left(\mathrm{CD}_{3}\right)(97)$ & $\mathrm{A}^{\prime \prime}$ & $58.9^{(<0.1)}$ & & $\tau\left(\mathrm{CD}_{3}\right)(98)$ & $69.2^{(0.5)}$ & & +10.3 & \\
\hline
\end{tabular}

${ }^{a}$ The observed and calculated intensities were normalized by the intensity of the strongest band of both cis and trans conformers. The normalized values are shown in parentheses. The calculated potential energy distributions on the basis of the ab initio harmonic force constant are also shown. ${ }^{b}$ From ref 5. Symbols: $v$, stretching; $\delta$, bending; $\gamma$, rocking; $\tau$, torsion; FR, involved in Fermi resonance.

tentatively assigned to the $\mathrm{C}-\mathrm{O}$ torsion overtone of cis- $\mathrm{CH}_{3}-$ $\mathrm{COOH}$. In this case, the anharmonicity of the $\tau(\mathrm{C}-\mathrm{O})$ mode in cis- $\mathrm{CH}_{3} \mathrm{COOH}$ is similar to that of the analogous mode of cis$\mathrm{HCOOH}\left(\approx 13 \mathrm{~cm}^{-1}\right) \cdot{ }^{13}$

Several low-intensity bands are unassigned in Tables 1 and 2 or assigned tentatively to overtones or combination modes. Some of them can also be due to matrix-site effects. It is not our purpose to discuss the assignment of those bands. It should be mentioned only that the spectrum of $\mathrm{cis}-\mathrm{CH}_{3} \mathrm{COOH}$ shows a relatively intense band at $1285.4 \mathrm{~cm}^{-1}$ that probably originates from a nonfundamental mode with enhanced intensity due to coupling with the very intense $\delta(\mathrm{COH})$ mode (at $\left.1271.9 \mathrm{~cm}^{-1}\right)$. It is assigned tentatively to the $v(\mathrm{C}-\mathrm{C})+\tau(\mathrm{C}-\mathrm{O})$ combination mode. In the case of $\mathrm{CD}_{3} \mathrm{COOD}$, both conformers exhibit a doublet in the region of the $v(\mathrm{C}-\mathrm{O})$ mode separated by 18 and $27 \mathrm{~cm}^{-1}$ for cis and trans, respectively. We believe that this is due to the coupling of the $v \mathrm{C}-\mathrm{O}$ mode with a nonfundamental mode rather than due to matrix site effects.

$193 \mathbf{~ n m}$ Photolysis. One of the motivations of this work was to investigate the possible conformational selectivity of UV photolysis of acetic acid. In an Ar matrix, conversion of cis$\mathrm{CH}_{3} \mathrm{COOH}$ and $\mathrm{cis}-\mathrm{CD}_{3} \mathrm{COOH}$ to the corresponding trans forms by tunneling is very fast, which limits the concentration of the cis conformer. Therefore, the influence of the molecular conformation on the photolysis of acetic acid is better studied for the $\mathrm{CD}_{3} \mathrm{COOD}$ isotopologue, due to its relatively slow cisto-trans tunneling. Indeed, for this deuterated molecule, the halflife of the cis conformer is approximately 5 days, whereas for cis- $\mathrm{CH}_{3} \mathrm{COOH}$ it is $16 \mathrm{s.}^{11}$ As already mentioned, the cis conformer appears as one of the products of UV photolysis of

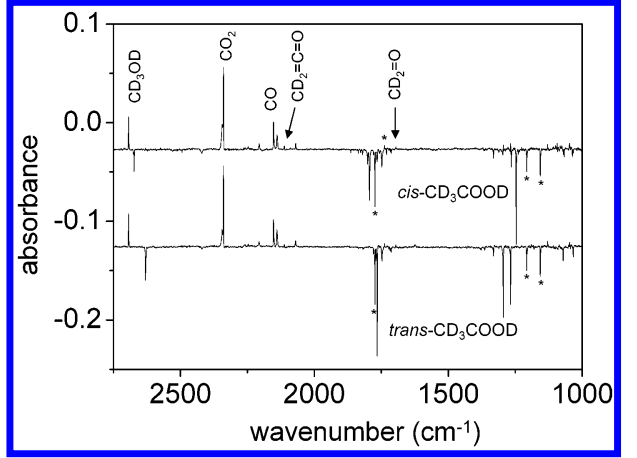

Figure 2. Difference IR absorption spectra showing the result of 193 $\mathrm{nm}$ photolysis of the cis and trans conformers of perdeuterated acetic acid in solid Ar at $8 \mathrm{~K}$. Bands marked with an asterisk are from $\mathrm{CD}_{3-}$ $\mathrm{COOH}$ present as an impurity in the sample.

trans- $\mathrm{CD}_{3} \mathrm{COOD}$, and vice versa. Thus, to minimize the effect of UV-induced rotamerization, UV photolysis of one conformer (trans or cis) was undertaken while the other conformer was pumped with resonant IR radiation. Excitation of the OD stretching overtone of the conformer produced by UV radiation converts it back to the starting conformer. The $v(\mathrm{OD})$ overtone is observed at 5167.8 and $5257.4 \mathrm{~cm}^{-1}$ for trans- and cis- $\mathrm{CD}_{3}$ COOD isolated in solid Ar.

The main photolysis products are molecular complexes involving $\mathrm{CO}_{2}$ or $\mathrm{CO}$, namely $\mathrm{CO}$ complexed with methanol (see later). No conformational dependence was found upon photolysis of $\mathrm{CD}_{3} \mathrm{COOD}$, as seen in Figure 2. We can suggest a number of possible reasons why the acetic acid photolysis is conformationally independent, in contrast to the photolysis of 
formic acid. If vibrational relaxation in the excited electronic state of acetic acid is faster than dissociation, as was suggested for excitation at 218 and $200 \mathrm{~nm},{ }^{22,23}$ then photodecomposition is expected to be a conformationally independent process. In formic acid, torsional randomization was assumed to be a slower process as compared to formation of the transition state for decomposition. ${ }^{15}$ In fact, it has been estimated recently that in the $S_{1}$ surface isomerization of formic acid occurs on a picosecond time scale, whereas decomposition takes place in a femtosecond time scale. ${ }^{33}$ In matrix-isolated formic acid, the $\mathrm{S}_{1}$ Franck-Condon geometry relaxes to a vibrationally excited ground state and decomposition results mainly in formation of molecular products. ${ }^{15}$ The same process was used to explain molecular elimination upon photolysis of formic acid in the gas phase. ${ }^{34}$ In contrast, it is known that the primary gas-phase photolysis products of acetic acid are mainly radicals $\left(\mathrm{CH}_{3} \mathrm{CO}\right.$, $\mathrm{OH}, \mathrm{CH}_{3}, \mathrm{COOH},{ }^{22-24,35}$ even though molecular elimination products upon UV broadband photolysis were reported in earlier works. ${ }^{36}$ This indicates that the decomposition takes place mainly on the excited-state surfaces rather than in the vibrationally excited ground state. The molecular products of solidstate photolysis of acetic acid, formed upon cage-induced recombination of the primary radicals, indicate that the branching ratio for radical formation is conformationally independent. The photodecomposition dynamics in acetic acid has been studied theoretically using the MP2 and CASSCF methods. ${ }^{17}$ In that study, it has been shown that the transition state for $\mathrm{C}-\mathrm{C}$ cleavage on the $\mathrm{T}_{1}$ surface has a geometry very similar to that of cis-acetic acid, whereas the transition state for $\mathrm{C}-\mathrm{O}$ cleavage on the $\mathrm{T}_{1}$ surface and for both $\mathrm{C}-\mathrm{C}$ and $\mathrm{C}-\mathrm{O}$ cleavages on the $S_{1}$ surface are connected geometrically to trans-acetic acid. ${ }^{17}$ This means that the branching ratio between radicals could in principle be affected by the molecular conformation. In practice, because $T_{1} \leftarrow S_{0}$ is a forbidden transition and at the $S_{1} / T_{1}$ crossing point the $T_{1}$ Franck-Condon geometry is already relaxed to a geometry bearing no memory of the initially excited conformer, decomposition to radicals on the $\mathrm{T}_{1}$ surface seems to be conformationally independent. On the $\mathrm{S}_{1}$ surface, the $\mathrm{C}-\mathrm{O}$ cleavage is the only energetically accessible process. Finally the UV-induced isomerization competes with photodecomposition upon $193 \mathrm{~nm}$ irradiation of acetic acid, as seen from the production of cis- $\mathrm{CD}_{3} \mathrm{COOD}$ upon irradiation of trans- $\mathrm{CD}_{3}$ COOD, and vice versa. This might be another reason for photodecomposition to be a conformationally independent process in acetic acid as opposed to formic acid, where isomerization does not compete appreciably with decomposition.

The easily identified photodecomposition products of $\mathrm{CD}_{3}$ COOD are methanol, ${ }^{37}$ carbon monoxide, and carbon dioxide..$^{38-40}$ In addition, we could detect also weaker bands from formaldehyde and ketene. ${ }^{41,42}$ These species are isolated as complexes with the corresponding photolysis product, as will be later discussed. The same products are observed upon photolysis of $\mathrm{CH}_{3} \mathrm{COOH}$, with some small differences in the branching ratios as compared with the deuterated isotopologue. Figure 3 is a difference spectrum showing the result of photolysis of $\mathrm{CH}_{3}$ $\mathrm{COOH}$ in solid Ar. In Table 3 the emerging bands upon photolysis of $\mathrm{CD}_{3} \mathrm{COOD}$ and $\mathrm{CH}_{3} \mathrm{COOH}$ are listed together with previously reported data on the relevant monomeric species isolated in Ar.

Most interestingly, this is the first time that methanol and carbon monoxide are among the products of molecular elimination channels upon photolysis of monomeric acetic acid. These products might be the result of recombination of acetyl and hydroxyl radicals formed on the $S_{1}$ or $T_{1}$ surfaces, ${ }^{17}$ which

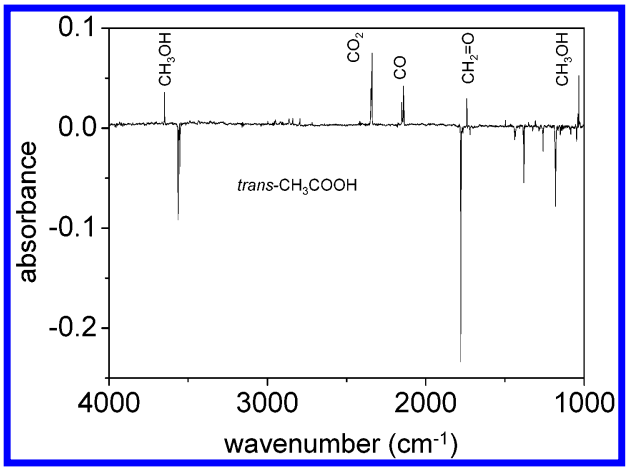

Figure 3. Difference IR absorption spectrum showing the result of $193 \mathrm{~nm}$ photolysis of trans- $\mathrm{CH}_{3} \mathrm{COOH}$ isolated in solid $\mathrm{Ar}$ at $8 \mathrm{~K}$.

remain in close contact within the same matrix cage after decomposition of acetic acid. Methanol and carbon monoxide could also be formed upon further photolysis of primary acetic acid decomposition products, for instance, photolysis of ketene in the presence of water. ${ }^{43}$ Figure 4 illustrates a possible photodecomposition scheme. According to this scheme, the final products are dictated by the recombination of radicals, which is caused by the matrix-cage effect. ${ }^{29}$ The matrix cage is known to affect substantially the decomposition dynamics of the isolated molecule due to the fact that, even for the light fragments, cage exit is a rather improbable phenomenon. Furthermore, because the molecular species formed as a result of permanent dissociation remain in the same cage, they might form stable complexes. In fact, photolysis of matrix isolated species has been used to prepare various 1:1 molecular complexes. ${ }^{44-49}$

Another product of photolysis of acetic acid is $\mathrm{CO}_{2}$. On the basis of the frequently used ratio of $\sim 10$ between $\mathrm{CO}_{2}$ and $\mathrm{CO}$ absorption cross sections, ${ }^{50,51}$ the $\mathrm{CO} / \mathrm{CO}_{2}$ product ratio upon photolysis is $\sim 5$. Methane is expected to be formed together with $\mathrm{CO}_{2}$, from recombination of the $\mathrm{CH}(\mathrm{D})_{3}$ and $\mathrm{OCOH}(\mathrm{D})$ radicals formed after $\mathrm{C}-\mathrm{C}$ bond cleavage on the $\mathrm{T} 1$ surface. ${ }^{17}$ Nevertheless, the bands of methane are not readily identified after photolysis of $\mathrm{CD}_{3} \mathrm{COOD}$ (Table 3 ), which is most probably due to the much smaller IR absorption cross section of methane modes as compared with $\mathrm{CO}_{2}$. In the photolysis of $\mathrm{CH}_{3} \mathrm{COOH}$ we assigned one band emerging at $1308.3 \mathrm{~cm}^{-1}$ to methane reported previously at $1307.7 \mathrm{~cm}^{-1} .52$ The $\mathrm{C}-\mathrm{H}$ stretching mode of the methane monomer is known to be a broad band in raregas matrixes. ${ }^{52}$ This can explain why this mode is not observed upon photodissociation of $\mathrm{CH}_{3} \mathrm{COOH}$ despite having a higher intrinsic intensity than the bending mode. ${ }^{53}$

A band at $2112.1 \mathrm{~cm}^{-1}$, rising upon photolysis of $\mathrm{CD}_{3} \mathrm{COOD}$, is assigned to the $v(\mathrm{C}=\mathrm{O})$ mode of deuterated ketene $\left(\mathrm{CD}_{2}=\right.$ $\mathrm{C}=\mathrm{O}$ ). In agreement, this mode is observed for $\mathrm{CH}_{2}=\mathrm{C}=\mathrm{O}$ in the $2134-2144 \mathrm{~cm}^{-1}$ region and it is predicted by ab initio calculations to shift toward lower frequencies by $21.6 \mathrm{~cm}^{-1}$ for $\mathrm{CD}_{2}=\mathrm{C}=\mathrm{O} .{ }^{42}$ It is the strongest mode of ketene, ${ }^{42}$ with an absorption cross section much larger than any other vibration of this species $\left(\sim 555\right.$ and $440 \mathrm{~km} / \mathrm{mol}$, calculated for $\mathrm{CH}_{2}=$ $\mathrm{C}=\mathrm{O}$ and $\mathrm{CD}_{2}=\mathrm{C}=\mathrm{O}$, respectively). The $2112.1 \mathrm{~cm}^{-1}$ band increases quickly in the earlier stages of photolysis and decreases upon long photolysis. This behavior is in agreement with the fact that ketene can also be photolyzed with 193-nm radiation. ${ }^{43}$ The estimated CO: $\mathrm{CD}_{2}=\mathrm{C}=\mathrm{O}$ ratio is $\sim 20: 1$, even in the earlier stages of photolysis. This means that the photolysis channel leading to production of ketene is minor or its formation rate is comparable with its decomposition in the present experimental conditions. Ketene is not readily identified as a product of photolysis of $\mathrm{CH}_{3} \mathrm{COOH}$ because the $v(\mathrm{C}=\mathrm{O})$ band of $\mathrm{CH}_{2}=$ $\mathrm{C}=\mathrm{O}$ overlaps with the absorption of carbon monoxide. 
TABLE 3: Comparison between the Observed IR Frequencies $\left(\mathrm{cm}^{-1}\right)$ for the $193 \mathrm{~nm}$ Photolysis Products of $\mathrm{CD}_{3} \mathrm{COOD}$ and $\mathrm{CH}_{3} \mathrm{COOH}$ with Reported Data on Monomeric $\mathrm{CD}_{3} \mathrm{OD} / \mathrm{CH}_{3} \mathrm{OH}, \mathrm{CD}_{4} / \mathrm{CH}_{4}, \mathrm{CO}_{2}, \mathrm{CO}, \mathrm{CD}_{2}=\mathrm{O} / \mathrm{CH}_{2}=\mathrm{O}$, and $\mathrm{CH}_{2}=\mathrm{C}=\mathrm{O}$ Isolated in Solid $\mathrm{Ar}^{a}$

\begin{tabular}{|c|c|c|c|c|c|c|c|c|}
\hline \multicolumn{2}{|c|}{$\begin{array}{c}\mathrm{CD}_{3} \mathrm{COOD} \\
\text { products }\end{array}$} & \multicolumn{2}{|c|}{ lit. data ${ }^{b}$} & mode & \multicolumn{2}{|c|}{ lit. data ${ }^{b}$} & \multicolumn{2}{|c|}{$\begin{array}{c}\mathrm{CH}_{3} \mathrm{COOH} \\
\text { products }\end{array}$} \\
\hline & & \multicolumn{2}{|c|}{$\mathrm{CD}_{3} \mathrm{OD}$} & & \multicolumn{2}{|c|}{$\mathrm{CH}_{3} \mathrm{OH}$} & & \\
\hline 2693.6 & $\mathrm{~m}$ & 2706.1 & $\mathrm{~m}$ & $v(\mathrm{OH})$ & 3667.3 & $\mathrm{~s}$ & 3649.6 & $\mathrm{~m}$ \\
\hline 2205.9 & w & 2219.1 & w & $v\left(\mathrm{CH}_{3}\right)$ & 3005.3 & $\mathrm{~m}$ & 2996.8 & vw \\
\hline 2258 & vw & 2254.3 & $\mathrm{~m}$ & $v\left(\mathrm{CH}_{3}\right)$ & 2961.9 & $\mathrm{~s}$ & 2949.2 & vw \\
\hline 2246 & vw & & & & & & & \\
\hline \multirow[t]{3}{*}{2070} & $\mathrm{w}$ & 2078.3 & $\mathrm{~m}$ & $v\left(\mathrm{CH}_{3}\right)$ & 2847.9 & $\mathrm{~s}$ & 2839.5 & $\mathrm{vw}$ \\
\hline & & 1031.3 & $\mathrm{~m}$ & $\delta\left(\mathrm{CH}_{3}\right)$ & 1474.1 & vw & & \\
\hline & & 1068.1 & $\mathrm{vw}$ & $\delta\left(\mathrm{CH}_{3}\right)$ & 1465.8 & vw & & \\
\hline 1129 & w & 1132.7 & $\mathrm{~m}$ & $\delta\left(\mathrm{CH}_{3}\right)$ & 1451.4 & vw & & \\
\hline 782.4 & $\mathrm{w}$ & 775.4 & $\mathrm{~m}$ & $\delta(\mathrm{COH})$ & 1335 & $\mathrm{~m}$ & 1351 & vw \\
\hline \multirow[t]{2}{*}{858.1} & vw & 860.4 & vw & $\rho\left(\mathrm{CH}_{3}\right)$ & 1157 & vw & & \\
\hline & & 1055.2 & vw & $\rho\left(\mathrm{CH}_{3}\right)$ & 1076.7 & vw & & \\
\hline \multirow[t]{5}{*}{978.8} & w & 983.4 & $\mathrm{~m}$ & $v(\mathrm{CO})$ & 1034.0 & vs & 1034 & $\mathrm{~s}$ \\
\hline & & & & $\tau(\mathrm{CO})$ & 240 & vs & & \\
\hline & & \multicolumn{2}{|c|}{$\mathrm{CD}_{4}^{c}$} & & \multicolumn{2}{|c|}{$\mathrm{CH}_{4}$} & & \\
\hline & & 2260.3 & $\mathrm{w}$ & $v\left(\mathrm{CH}_{3}\right)$ & 3037.0 & $\mathrm{~s}$ & & \\
\hline & & 993.4 & $\mathrm{w}$ & $\delta\left(\mathrm{CH}_{3}\right)$ & 1307.7 & $\mathrm{~s}$ & 1308.3 & $\mathrm{w}$ \\
\hline \multicolumn{9}{|c|}{$\mathrm{CO}_{2}{ }^{d}$} \\
\hline 2347.5 & br & 2345.2 & vs & $v\left(\mathrm{CO}_{2}\right)$ & & & 2345.6 & br \\
\hline 2344.5 & br & & & & & & 2344.4 & br \\
\hline 2341.6 & br & & & & & & 2340.2 & $\mathrm{~s}$ \\
\hline 2339.2 & vs & 2339.0 & vs & $v\left(\mathrm{CO}_{2}\right)$ & & & 2338.9 & vs \\
\hline 663.9 & $\mathrm{~m}$ & 663.3 & $\mathrm{~m}$ & $\delta\left(\mathrm{CO}_{2}\right)$ & & & 663.9 & $\mathrm{~m}$ \\
\hline 662.3 & $\mathrm{~m}$ & 661.8 & $\mathrm{~m}$ & $\delta\left(\mathrm{CO}_{2}\right)$ & & & 662.3 & $\mathrm{~m}$ \\
\hline \multicolumn{9}{|c|}{$\mathrm{CO}^{e}$} \\
\hline 2152.5 & $\mathrm{~m}$ & & & & & & 2152.0 & $\mathrm{~m}$ \\
\hline 2151.9 & $\mathrm{~m}$ & & & & & & 2151.6 & $\mathrm{~m}$ \\
\hline 2151.5 & $\mathrm{sh}$ & & & & & & 2151.0 & sh \\
\hline \multirow[t]{2}{*}{2150.3} & $\mathrm{~m}$ & & & & & & 2149.9 & $\mathrm{~m}$ \\
\hline & & & & & & & 2141.1 & sh \\
\hline 2140.0 & $\mathrm{~m}$ & 2140.1 & $\mathrm{sh}$ & $v(\mathrm{C} \equiv \mathrm{O})^{\mathrm{D}}$ & & & 2140.2 & $\mathrm{~m}$ \\
\hline \multirow[t]{2}{*}{2139.3} & $\mathrm{~m}$ & 2138.5 & $\mathrm{~s}$ & $v(\mathrm{C} \equiv \mathrm{O})^{\mathrm{M}}$ & & & 2140.0 & $\mathrm{~m}$ \\
\hline & & 2136.7 & sh & $v(\mathrm{C} \equiv \mathrm{O})^{\mathrm{M}}$ & & & 2139.4 & $\mathrm{sh}$ \\
\hline \multirow[t]{4}{*}{2138} & br & & & & & & 2138.3 & $\mathrm{~m}$ \\
\hline & & \multicolumn{2}{|c|}{$\mathrm{CD}_{2}=\mathrm{O}$} & & \multicolumn{2}{|c|}{$\mathrm{CH}_{2}=\mathrm{O}$} & & \\
\hline & & 2176.8 & $\mathrm{~s}$ & $v\left(\mathrm{CH}_{2}\right)$ & 2863.0 & $\mathrm{~s}$ & 2863 & $\mathrm{vw}$ \\
\hline & & 2069.1 & $\mathrm{~s}$ & $v\left(\mathrm{CH}_{2}\right)$ & 2797.1 & $\mathrm{~s}$ & 2794.2 & w \\
\hline \multirow[t]{6}{*}{1696.1} & $\mathrm{vw}$ & 1697.8 & $\mathrm{~s}$ & $v(\mathrm{C}=\mathrm{O})$ & 1742.0 & $\mathrm{~s}$ & 1739.9 & $\mathrm{~m}$ \\
\hline & & 1099.1 & vw & $\delta\left(\mathrm{CH}_{2}\right)$ & 1498.8 & $\mathrm{~m}$ & 1496.7 & w \\
\hline & & 987.1 & $\mathrm{w}$ & $\rho\left(\mathrm{CH}_{2}\right)$ & 1244.8 & w & & \\
\hline & & 938.3 & vw & $\omega\left(\mathrm{CH}_{2}\right)$ & 1168.0 & $\mathrm{w}$ & & \\
\hline & & & & & \multicolumn{2}{|c|}{$\mathrm{CH}_{2}=\mathrm{C}=\mathrm{O}$} & & \\
\hline & & & & $v\left(\mathrm{CH}_{2}\right)$ & 3062 & $\mathrm{~m}$ & & \\
\hline \multirow[t]{4}{*}{2112.1} & w & & & $v(\mathrm{C}=\mathrm{O})$ & 2140 & $\begin{array}{l}111 \\
\text { vs }\end{array}$ & $2140^{f}$ & $\mathrm{~m}$ \\
\hline & & & & $\delta\left(\mathrm{CH}_{2}\right)$ & $\begin{array}{r}2140 \\
974\end{array}$ & $\mathrm{~m}$ & & \\
\hline & & & & $\rho(\mathrm{C}=\mathrm{O})$ & 579 & $\mathrm{~m}$ & & \\
\hline & & & & $\rho(\mathrm{C}=\mathrm{O})$ & 525 & $\mathrm{~s}$ & & \\
\hline
\end{tabular}

${ }^{a}$ Symbols: vs, very strong; s, strong; m, medium; w, weak; vw, very weak; br, broad; sh, shoulder; $\nu$, stretching; $\delta$, bending; $\rho$, rocking; $\omega$, wagging and $\tau$, torsion. ${ }^{b}$ Data were taken from refs $37-42$ and 52. ${ }^{c}$ Data of $\mathrm{CD}_{4}$ isolated in Kr matrixes taken from ref 52. ${ }^{d}$ The splitting of the $\mathrm{CO}_{2}$ bands was assigned to molecules isolated in different sites in ref $40 .{ }^{e}$ The letters $\mathrm{M}$ and $\mathrm{D}$ stand for monomer and dimer, respectively. ${ }^{38,39}$ ${ }^{f}$ Band overlapping with the envelope of bands from $\mathrm{CO}$, see text for a detailed explanation.

Nevertheless, it can be seen in Figure 5 that the band shape of the carbon monoxide absorption near $2140 \mathrm{~cm}^{-1}$ changes significantly during photolysis, and the overlapping ketene band can cause this modification. Furthermore, after 600 pulses there is a band at $1593.9 \mathrm{~cm}^{-1}$ that can be due to formation of complexed water, which is the other molecular species produced together with ketene. ${ }^{15}$ This band disappears after 3300 pulses, which probably indicates that water reacts with the photolysis products of ketene. The major products of $193 \mathrm{~nm}$ photolysis of ketene are $\mathrm{CH}_{2}+\mathrm{CO}$ and $\mathrm{HC} \equiv \mathrm{CO}+\mathrm{H}$ in a $1: 3$ proportion. ${ }^{15}$ Because these radicals will be in close contact with water inside the matrix cage, they can react with water, forming various radicals, which react further producing at some point stable molecular species (formaldehyde, carbon monoxide, and molecular hydrogen; see Figure 4). Notice that formaldehyde $\left(\mathrm{CH}_{2}=\mathrm{O}\right)$ might also be generated from photolysis of the methanol molecules formed directly from recombination of the acetyl and hydroxyl radicals (Figure 4). ${ }^{54}$ The formation of formaldehyde from photolysis of $\mathrm{CH}_{3} \mathrm{COOH}$ is evident because we have detected the four strongest vibrations of this molecule (see Table 3). However, only the $v \mathrm{C}=\mathrm{O}$ band of deuterated formaldehyde was observed $\left(1696.1 \mathrm{~cm}^{-1}\right)$ upon photolysis of 


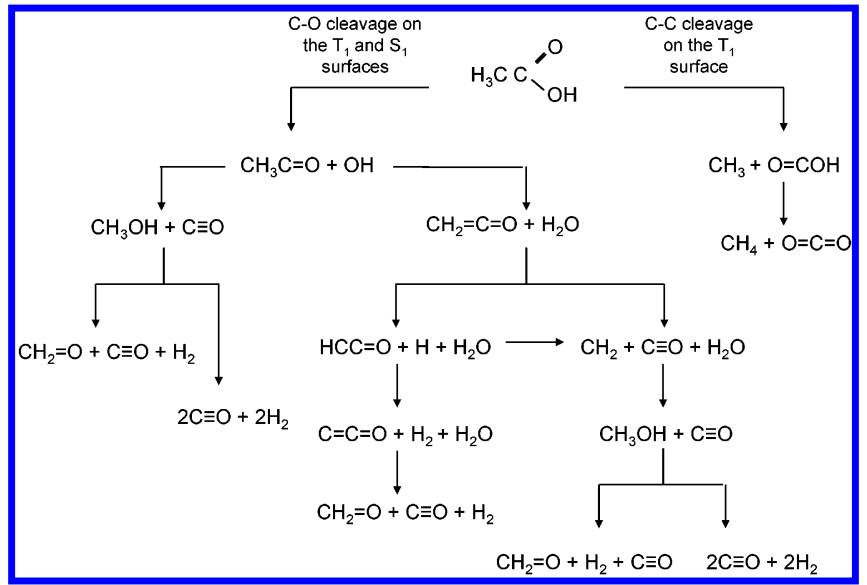

Figure 4. Photodecompositiom channels of acetic acid. In addition to the presented decomposition channels, there is also a possibility of recombination of the primary radicals back to acetic acid in the vibrationally excited ground state that can dissociate directly into the observed molecular products of thermal decomposition $\left(\mathrm{CH}_{2}=\mathrm{C}=\mathrm{O}\right.$ $+\mathrm{H}_{2} \mathrm{O}$ and $\mathrm{CH}_{4}+\mathrm{CO}_{2}$ ).

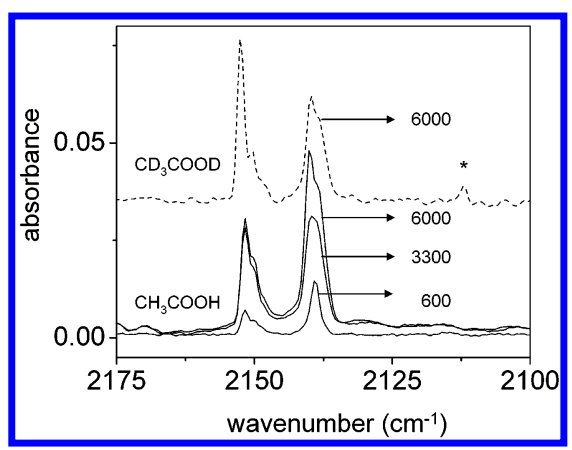

Figure 5. IR absorption bands emerging in the $2175-2100 \mathrm{~cm}^{-1}$ region upon $193 \mathrm{~nm}$ photolysis of $\mathrm{CH}_{3} \mathrm{COOH}$ with 600, 3300, and 6000 pulses. The same region is shown for photolysis of $\mathrm{CD}_{3} \mathrm{COOD}(--)$ after 6000 pulses of $193 \mathrm{~nm}$ radiation for comparison. The band marked with an asterisk was assigned to deuterated ketene $\left(\mathrm{CD}_{2}=\mathrm{C}=\mathrm{O}\right)$.

$\mathrm{CD}_{3} \mathrm{COOD}$. This emerging band is very weak, indicating that formaldehyde is a minor product of photolysis of $\mathrm{CD}_{3} \mathrm{COOD}$.

Complex between Carbon Monoxide and Methanol. Methanol formed upon $193 \mathrm{~nm}$ photolysis of acetic acid in solid $\mathrm{Ar}$ is produced together with carbon monoxide in the same matrix cage. It is known that when methanol is isolated in an Ar matrix doped with $2 \%$ of carbon monoxide a 1:1 complex is formed between the two molecules. ${ }^{55}$ On one hand, the bands of methanol are consistent with the formation of one specific type of complex (see discussion later). On the other hand, carbon monoxide can be produced upon solid-state photolysis of acetic acid via various mechanisms, such as photolysis of ketene in the presence of water, photolysis of methanol, and direct recombination of acetyl and hydroxyl radical. From the possible decomposition pathways shown in Figure 4, carbon monoxide could be sharing the matrix cage with methanol, formaldehyde, and molecular hydrogen or with another carbon monoxide molecule and hydrogen. In fact, the produced carbon monoxide upon UV irradiation of acetic acid exhibits two sets of bands separated by $\sim 10 \mathrm{~cm}^{-1}$, indicating that at least two different types of complexes with $\mathrm{CO}$ are produced.

Previously, a red shift $\left(18 \mathrm{~cm}^{-1}\right)$ was observed for the $\nu$ (OH) mode of $\mathrm{CH}_{3} \mathrm{OH}$ isolated in an $\mathrm{Ar}$ matrix containing $2 \%$ of $\mathrm{CO} .{ }^{55}$ This shift agrees with our data on $v(\mathrm{OH})$ of $\mathrm{CH}_{3} \mathrm{OH}$ formed upon photolysis of $\mathrm{CH}_{3} \mathrm{COOH}$ (Table 3). A proportional shift was observed in the $v(\mathrm{OD})$ mode of $\mathrm{CD}_{3} \mathrm{OD}$ complexed with $\mathrm{CO}\left(13 \mathrm{~cm}^{-1}\right)$ as compared with the monomer isolated in

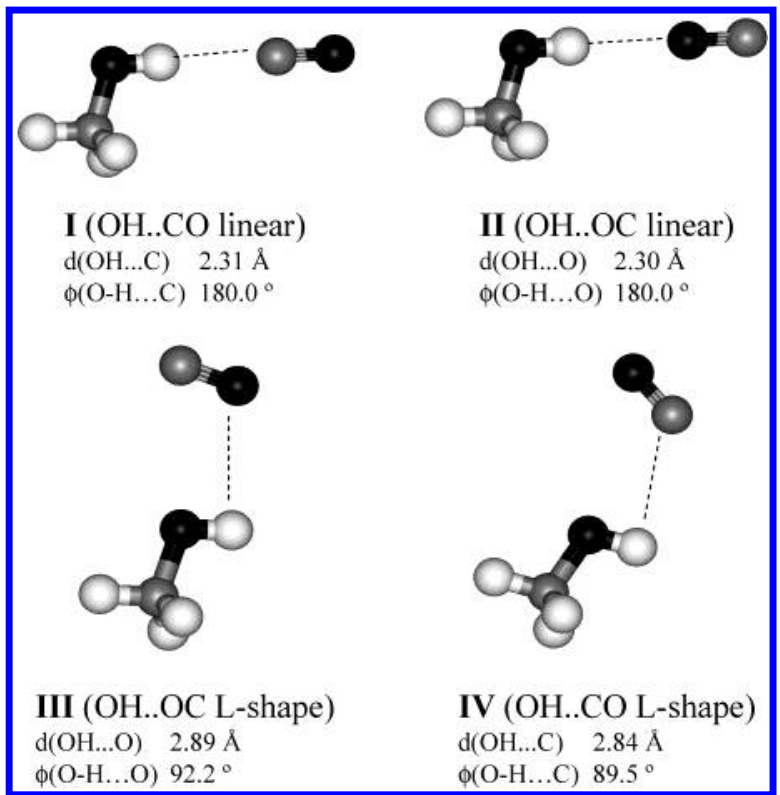

Figure 6. Optimized geometries for the 1:1 complex between methanol and carbon monoxide. Relevant geometrical parameters of complexes are shown.

TABLE 4: Comparison between Predicted [MP2/ 6-311 $++(2 d, 2 p)]$ Frequency Shifts for the Four Stable Structures of the Complex between Methanol and Carbon Monoxide with Respect to the Free Monomers and the Observed Shifts for the Complex Isolated in Solid Ar

\begin{tabular}{cccccc}
\hline $\begin{array}{c}\text { free } \\
\text { monomer } \\
\left(\mathrm{cm}^{-1}\right)\end{array}$ & $\begin{array}{c}\text { I } \\
\text { OH } \cdots \text { CO } \\
\text { linear }\end{array}$ & $\begin{array}{c}\text { II } \\
\text { OH } \cdots \text { OC } \\
\text { linear }\end{array}$ & $\begin{array}{c}\text { III } \\
\text { OH } \cdots \text { OC } \\
\text { L-shape }\end{array}$ & $\begin{array}{c}\text { IV } \\
\text { OH } \cdots \text { CO } \\
\text { L-shape }\end{array}$ & obsd $^{a}$ \\
\hline 3902.9 & -26.8 & +12.0 & -7.4 & -9.1 & -17.7 \\
3205.0 & -7.5 & -2.2 & +1.1 & -0.7 & -8.5 \\
3144.2 & -11.0 & -4.4 & +1.8 & +1.5 & -12.7 \\
3075.1 & -8.1 & -3.4 & +1.0 & +0.7 & -8.4 \\
2120.1 & +12.5 & -3.3 & -1.6 & +4.3 & +12 \\
1544.8 & +0.3 & +0.2 & -0.1 & -0.2 & \\
1532.1 & +0.2 & +0.2 & -0.5 & -0.7 & \\
1508.1 & -0.9 & -0.3 & -0.4 & -0.7 & \\
1387.3 & +31.8 & +12.2 & -0.4 & -1.4 & +16.3 \\
1191.2 & +0.2 & 0.0 & +0.3 & -0.2 & \\
1095.4 & +19.0 & +7.3 & 0.0 & +5.1 & \\
1053.9 & +9.8 & +3.5 & -0.1 & +0.2 & -0.3 \\
288.3 & +195.1 & +76.9 & +9.8 & +29.3 & \\
$E_{\text {int }}^{b}$ & -1.66 & -0.60 & -0.72 & -1.06 & \\
& $(-1.24)$ & $(-0.48)$ & $(-0.53)$ & $(-0.56)$
\end{tabular}

${ }^{a}$ Observed shifts with respect to the bands of the free monomers isolated in an Ar matrix. ${ }^{37}{ }^{b}$ BSSE corrected interaction energy (kJ $\left.\mathrm{mol}^{-1}\right)$ calculated at the at the MP2/6-311++(2d,2p) level and values taken form ref 56 in parentheses.

solid Ar. ${ }^{37}$ The red shift of the $v(\mathrm{OH})$ frequency of methanol upon complexation with $\mathrm{CO}$ disagrees with the earlier computationally predicted blue shift for all stable geometries of this complex. ${ }^{56}$ In view of this disagreement, we performed geometry optimizations and energy calculations based on those geometries with a more complete basis set. In Figure 6 the four stable geometries of the complex formed between $\mathrm{CH}_{3} \mathrm{OH}$ and $\mathrm{CO}$ are shown. The energetics of these structures and the expected frequency shifts for the complexed units with respect to the free monomers appear in Table 4.

From the four optimized geometries of the complex, two have a linear arrangement of the $\mathrm{CO}$ molecule with respect with the $\mathrm{OH}$ bond (I and II) and two have an L-shape arrangement (III and IV). Structure I has the $\mathrm{OH} \cdots \mathrm{CO}$ interaction whereas structure II has an interaction of the $\mathrm{OH} \cdots$ OC type. Both of 
them are predicted to have the $\mathrm{OH} \cdots \mathrm{O} / \mathrm{C}$ distances and $\mathrm{O}-\mathrm{H}$. $\cdot \mathrm{O} / \mathrm{C}$ angles characteristic of interactions via hydrogen bonds $\left(2.3 \AA\right.$ and $\left.180^{\circ}\right)$, as shown in Figure 6. In structure III the oxygen atom of $\mathrm{CO}$ is closer to the hydrogen atom of the hydroxyl group in methanol, whereas in structure IV it is the carbon atom of $\mathrm{CO}$ that is closer to the hydroxylic hydrogen. For III and IV, the $\mathrm{OH} \cdots \mathrm{O}$ and $\mathrm{OH} \cdots \mathrm{C}$ calculated distances are 2.9 and $2.8 \AA$, respectively, and the $\mathrm{O}-\mathrm{H} \cdots \mathrm{O} / \mathrm{C}$ angles deviate from the characteristic values of hydrogen bonded systems. The energies of the stable geometries of the $1: 1$ complex between methanol and $\mathrm{CO}$ are in qualitative agreement with the previously reported data. ${ }^{56}$ The only difference is the somewhat increased stability of structure IV with respect to the other structures. Our calculations predict a complexation-induced red shift in the $v(\mathrm{OH})$ mode of methanol for structures I, III, and IV and a blue shift for complex II.

The formation of complex II in the matrix can be ruled out because the predicted complexation shift of the $v(\mathrm{OH})$ is positive (blue) whereas the observed shift is negative (red). Among the three structures exhibiting a complexation-induced red shift in the $v(\mathrm{OH})$ mode, complex I exhibits vibrations in good agreement with the experiment, and it has the highest interaction energy. This is particularly evident for $v(\mathrm{OH})$, the three $v(\mathrm{CH})$, and the $\delta(\mathrm{COH})$ modes (observed shifts of $-26.8,-7.5,-11.0$, -8.1 , and +31.8 and the corresponding predicted values -17.7 , $-8.5,-12.7,-8.4$, and +16.3 ). For the most stable complex structure, calculations predict a blue shift of $12.5 \mathrm{~cm}^{-1}$ on the $\nu \mathrm{C} \equiv \mathrm{O}$ vibration, in good agreement with the observed shift of about $+12 \mathrm{~cm}^{-1}$ for the high-frequency set of bands of CO. Thus, according to the calculations, the high-frequency set of bands of CO $\left(\sim 2150 \mathrm{~cm}^{-1}\right)$ should be assigned to complex I. The identification of complex I is further supported by the fact that the predicted effect of deuteration on the complexation induced shift (a $7 \mathrm{~cm}^{-1}$ smaller red shift for $v \mathrm{OD}$ ) agrees with the observed isotopic effect (smaller red shift by $5 \mathrm{~cm}^{-1}$ ). The predicted effect of deuteration on the shift of the $v(\mathrm{C} \equiv \mathrm{O})$ band is very small $\left(0.3 \mathrm{~cm}^{-1}\right)$ so that it gives no indication about the complex geometry. We did not find strong experimental indications in the $v(\mathrm{OH})$ region of complexes III and IV. In the $v(\mathrm{C} \equiv \mathrm{O})$ region, the bands observed at $\sim 2140 \mathrm{~cm}^{-1}$ may originate from the $\mathrm{CO}$ dimer isolated in solid $\mathrm{Ar}^{38,39}$ In the present experiments, the $\mathrm{CO}$ dimers can be formed upon photolysis of either methanol or ketene (see Figure 4). The possibility of ternary complexes involving $\mathrm{CO}$, formaldehyde, and molecular hydrogen producing bands near the free monomer band cannot be excluded.

Upon annealing the matrix at $25 \mathrm{~K}$ after photolysis of $\mathrm{CH}_{3}$ $\mathrm{COOH}$, the $v(\mathrm{OH})$ band $\left(3649.6 \mathrm{~cm}^{-1}\right)$ practically disappears and three new bands appear at $3647.4,3646.5$, and $3645.3 \mathrm{~cm}^{-1}$. A similar intensity reorganization takes place for the $v(\mathrm{C} \equiv \mathrm{O})$ bands assigned to complex I: the envelope of bands at higher frequency decreases and a new set of bands appear shifted by $\sim 4 \mathrm{~cm}^{-1}$ from the decreasing bands (see Figure 7). The observed intensity reorganization is not consistent with conversion to a different complex geometry. In the present case, where only the most stable complex structure is observed upon photolysis, annealing the matrix at $25 \mathrm{~K}$ is not expected to decrease its concentration. When photolysis produces a distribution of conformers that is not in thermal equilibrium, ${ }^{47}$ annealing the matrix should lead to conversion of the less stable complexes into the lower energy forms. Instead we observed the decrease of bands assigned to the most stable complex. This makes us suggest that the observed modifications are caused by thermal relaxation of the matrix local surrounding, allowing a more

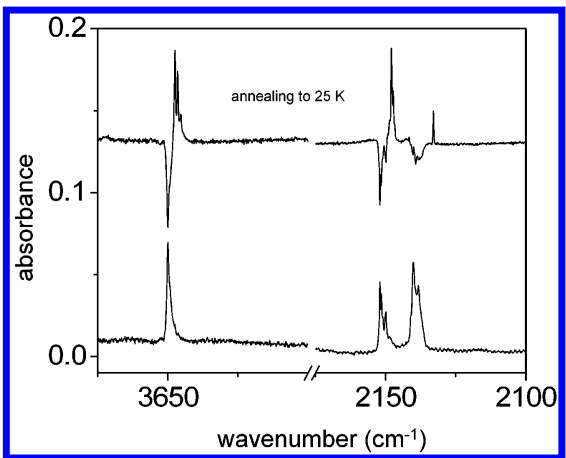

Figure 7. Thermally induced changes on the methanol $(v(\mathrm{OH})$ mode $)$ and $\mathrm{CO}$ bands upon annealing at $25 \mathrm{~K}$. The lower trace shows the spectrum collected after photolysis of acetic acid in solid Ar at $8 \mathrm{~K}$. The upper trace is the difference spectra showing the effect of annealing at $25 \mathrm{~K}$.

suitable orientation of the complex within the cage, in other words, conversion of the matrix sites. The intensity ratio of the increasing and decreasing bands upon annealing is $\sim 1$, which supports the fact that the same complex structures produces both sets of bands by taking into account that the $v(\mathrm{OH})$ absolute intensity is very sensitive to the complex geometry. In fact, the calculated $v(\mathrm{OH})$ intensities have a ratio of $5: 3: 1: 1$ between complexes I:II:III:IV.

There is also a broad feature centered at $\sim 2140 \mathrm{~cm}^{-1}$ whose intensity decreases upon annealing to $25 \mathrm{~K}$ whereas a new band appears at $2133 \mathrm{~cm}^{-1}$. It is not clear if these bands are related to each other, and the origin of the new narrow band remains unknown. In fact, interpretation of the spectral changes upon annealing are complicated by the fact that there is a small amount of hydrogen atoms that escape the cage during photolysis and can be thermally mobilized. This is a known phenomenon occurring during annealing of a matrix where a molecular species containing hydrogen was photolyzed. ${ }^{29,57,58}$ A strong support for mobility of thermally activated hydrogen atoms is the appearance of the band at $1862.4 \mathrm{~cm}^{-1}$, which is in good agreement with the very strong band observed for the free $\mathrm{HCO}$ radical in Ar matrixes $\left(1863 \mathrm{~cm}^{-1}\right) .{ }^{59}$ In the present experimental conditions, the $\mathrm{H}$ atom mobility is most probably a local process rather than a global process.

Photolysis Branching Ratios. After identification of the acetic acid photolysis products we can estimate the branching ratios for the proposed photolysis channels. The lack of information on the formation yield of the transient radicals prevents us from clarifying the source of the $\mathrm{CO}$ complexes giving bands at $\sim 2140 \mathrm{~cm}^{-1}$. Nevertheless, using the formaldehyde bands we can estimate the percentage of $\mathrm{CO}$ molecules involved in ternary complexes with formaldehyde and molecular hydrogen. The $v(\mathrm{C}=\mathrm{O})$ mode of ketene absorbs at $2140 \mathrm{~cm}^{-1}$ in solid Ar, but the relative amount of ketene formed is very small and we neglected its contribution to the envelope of bands around $2140 \mathrm{~cm}^{-1}$. The integrated intensities of the photolysis products, normalized by their intrinsic intensity (calculated or experimental), were used to estimate the proportion of the photolysis channels. The bands at $2150 \mathrm{~cm}^{-1}$ were used for complex I between methanol and $\mathrm{CO}$. We chose the $\mathrm{CO}$ band (instead of $v \mathrm{OH}$ of methanol) because computationally its intrinsic intensity is practically unchanged upon complexation with methanol. The carbon dioxide bands at $\sim 2340 \mathrm{~cm}^{-1}$ were used to estimate the importance of the $\mathrm{C}-\mathrm{C}$ cleavage channel.

As a result, $29 \%$ of the acetic acid molecules yield methanol plus carbon monoxide complexes, $15 \%$ yield carbon monoxide complexed with formaldehyde and molecular hydrogen, 39\% 
yield quaternary complexes of two carbon monoxide molecules and two hydrogen molecules and, finally, $17 \%$ dissociate to carbon dioxide and methane. Even if we assumed that the absorption of ketene contributes to a half of the intensity of the envelope of bands at $2140 \mathrm{~cm}^{-1}$ (which is definitely an overestimate), the percentage of ketene formed upon $193 \mathrm{~nm}$ irradiation of acetic acid would be small $(\sim 5 \%)$. In this case we would obtain $37 \%, 17 \%, 20 \%$, and $21 \%$ for the channels connected with $\mathrm{CO}+\mathrm{CH}_{3} \mathrm{OH}$ (complex I), $\mathrm{CO}+\mathrm{CH}_{2}=\mathrm{O}+$ $\mathrm{H}_{2}$ (ternary complex), $2 \mathrm{CO}+2 \mathrm{H}_{2}$ (quaternary complex), and $\mathrm{CO}_{2}+\mathrm{CH}_{4}$ complexes, respectively.

The distribution of photodecomposition products is in agreement with the fact that the $\mathrm{C}-\mathrm{C}$ cleavage, generating carbon dioxide and methane, occurs only on the $\mathrm{T}_{1}$ surface due to energetic restrictions. ${ }^{17}$ On the other hand, $\mathrm{C}-\mathrm{O}$ cleavage occurs both on the $S_{1}$ and $T_{1}$ surfaces, meaning that it has a higher probability than the $\mathrm{C}-\mathrm{C}$ cleavage. Although the intersystem crossing from $S_{1}$ to $T_{1}$ is a spin forbidden process, it was concluded that structural similarities between the crossing point of these two surfaces and the $S_{1}$ minimum indicate that this process can happen to a noticeable extent. ${ }^{17}$

Photolysis of perdeuterated acetic acid shows somewhat different branching ratios when compared with $\mathrm{CH}_{3} \mathrm{COOH}$. In the case of $\mathrm{CD}_{3} \mathrm{COOD}$, we can evaluate directly the amount of ketene formed from its $v(\mathrm{C}=\mathrm{O})$ band at $2112 \mathrm{~cm}^{-1}$. The estimated percentage of the different products are 45:5:33:16:1 for channels connected with $\mathrm{CO}+\mathrm{CH}_{3} \mathrm{OH}: \mathrm{CO}+\mathrm{CH}_{2}=\mathrm{O}+$ $\mathrm{H}_{2}: 2 \mathrm{CO}+2 \mathrm{H}_{2}: \mathrm{CO}_{2}+\mathrm{CH}_{4}: \mathrm{CD}_{2}=\mathrm{C}=\mathrm{O}+\mathrm{H}_{2} \mathrm{O}$. Compared with the photodissociation of $\mathrm{CH}_{3} \mathrm{COOH}$, these numbers indicate a considerable difference in the efficiency of the channels leading to formation of $\mathrm{CO}$, formaldehyde, and molecular hydrogen. This is evidenced by the difference in the relative intensity of the $\mathrm{CO}$ bands at 2140 and $2150 \mathrm{~cm}^{-1}$ upon photolysis of both isotopologues (Figure 5). The deuteration-induced changes in the branching ratios can be caused by isotopic effects on the processes in the scheme presented in Figure 4; however, it is difficult to specify them. For instance, these can include isotope effects of the absorption cross-section of ketene, formaldehyde, methane, methanol, and water at $193 \mathrm{~nm}$.

\section{Conclusions}

The results of this work can be separated into four parts:

1. We have analyzed the vibrational spectroscopy of $c i s$-acetic acid isolated in solid Ar, which was produced using vibrational excitation of the trans form. The vibrational assignment for various isotopologues was given for the cis form, and some bands were reassigned for the trans form (see Tables 1 and 2).

2. The perdeuterated isotopologue was used to test the conformational selectivity of the solid-state photolysis $(193 \mathrm{~nm})$ of acetic acid. No conformational dependence of the acetic acid photodissociation was found. This was explained in terms of decomposition on the excited-state surfaces leading primarily to unselective radical formation.

3. Upon $193 \mathrm{~nm}$ irradiation, acetic acid isolated in an $\mathrm{Ar}$ matrix decomposes permanently into a number of molecular complexes (see Figure 4 and Table 3 ). The photodecomposition dynamics for the isolated molecule is complicated, and not all channels are fully understood at the moment. It involves reaction of the radicals formed as primary products and further photodissociation of those secondary products. The major photolysis products are methanol complexed with carbon monoxide, the quaternary complex involving two carbon monoxide molecules and two hydrogen molecules, ternary complexes between carbon monoxide, formaldehyde, and probably molecular hydrogen, and carbon monoxide complexed with methane. Ketene, which is the main product of thermal decomposition of acetic acid, was detected only in small amounts $(\leq 5 \%)$ upon solid-state photolysis of acetic acid, and it is further photolyzed by $193 \mathrm{~nm}$ radiation, which makes estimation of its production conditional. In fact, apart from methane and carbon dioxide, all the molecular products observed could be explained in terms of photochemistry of the ketene-water complex.

4. The 1:1 complex between methanol and carbon monoxide was studied on the basis of ab initio calculations. We observed the most stable form of the complex, described by a planar structure with the $\mathrm{OH} \cdots \mathrm{CO}$ hydrogen bond. Upon annealing at $25 \mathrm{~K}$, the complex structure undergoes small modifications, which are explained in terms of thermal reorganization of the local matrix morphology.

Acknowledgment. The Academy of Finland is thanked for financial support. E.M. and R. F. acknowledge the Portuguese Foundation for Science and Technology (Ph.D. grant SFRH/ BD/4863/2001 and POCTI/QUI/43366/2001). Dr. Mika Pettersson is thanked for valuable discussions.

Supporting Information Available: Frequencies and intensities for $\mathrm{CH}_{3} \mathrm{COOD}$ and $\mathrm{CD}_{3} \mathrm{COOH}$. This material is available free of charge via the Internet at http://pubs.acs.org.

\section{References and Notes}

(1) Senent, M. L. Mol. Phys. 2001, 99, 1311.

(2) Haurie, M.; Novak, A. J. Chim. Phys. 1965, 62, 137.

(3) Wilmshurst, J. K. J. Chem. Phys. 1956, 6, 1171.

(4) Weltner, W. J. Am. Chem. Soc. 1955, 77, 3941.

(5) Berney, C. V.; Redington, R. L.; Lin, K. C. J. Chem. Phys. 1970 , 53,1713 .

(6) Burneau, A.; Génin, F.; Quilès, F. Phys. Chem. Chem. Phys. 2000, 2,5020

(7) Nielsen, O. F.; Lund, P.-A. J. Chem. Phys. 1983, 78, 652.

(8) Johnson, M. R.; Neumann, M.; Nicolai, B.; Smith, P.; Kearly, G. J. Chem. Phvs. 1997, 215, 343.

(9) Kosugi, K.; Makabayashy, T.; Nishi, N. Chem. Phys. Lett. 1998, $291,25$.

(10) Grenie, Y.; Cornut, J.-C.; Lassegues, J.-C. J. Chem. Phys. 1971 55,5844 .

(11) Maçôas, E. M. S.; Khriachtchev, L.; Pettersson, M.; Fausto, R. Räsänen, M. J. Am. Chem. Soc. 2003, 125, 16188.

(12) Khriachtchev, L.; Lundell, J.; Isoniemi, E.; Räsänen, M. J. Chem. Phys. 2000, 113, 4265.

(13) Maçôas, E. M. S.; Lundell, J.; Pettersson, M.; Khriachtchev, L.; Fausto, R.; Räsänen, M. J. Mol. Spectrosc. 2003, 219, 70.

(14) Pettersson, M.; Lundell, J.; Khriachtchev, L.; Räsänen, M. J. Am. Chem. Soc. 1997, 119, 11715.

(15) Khriachtchev, L.; Maçôas, E. M. S.; Pettersson, M.; Räsänen, M. J. Am. Chem. Soc. 2002, 124, 10994.

(16) Goez, M. Angew. Chem., Int. Ed. 2003, 42, 2336

(17) Fang, W.-H.; Liu, R.-Z.; Zheng, X.; Phillips, D. L. J. Org. Chem 2002, 67, 8407 .

(18) Moreira, I. P. R. J. Mol. Struct. (THEOCHEM) 1999, 466, 119 (19) Butkovskaya, N. I.; Manke, G. II; Setser, D. W. J. Phys. Chem. 1995, 99, 11115.

(20) Longfellow, C. A.; Lee, Y. T. J. Phvs. Chem. 1995, 99, 15532.

(21) Owrutsky, J. C.; Baronavski, A. P. J. Chem. Phys. 1999, 111, 7329.

(22) Hunnicutt, S. S.; Waits, L. D.; Guest, J. A. J. Phys. Chem. 1991, 95,562 .

(23) Hunnicutt, S. S.; Waits, L. D.; Guest, J. A. J. Phys. Chem. 1989, 93,5188 .

(24) Peterman, D. R.; Daniel, R. G.; Horwitz, R. J.; Guest, J. A. Chem. Phys. Lett. 1995, 236, 564.

(25) Pettersson, M.; Khriachtchev, L.; Jolkkonen, S.; Räsänen, M. J. Phys. Chem. A 1999, 103, 9154.

(26) Bondybey, V. E.; Brus, L. E. J. Chem. Phys. 1975, 62, 620.

(27) Schriever, R.; Chergui, M.; Schwentner, N. J. Phvs. Chem. 1991, 91,6124 .

(28) Gödderz, K. H.; Schwentner, N.; Chergui, M. J. Chem. Phvs. 1996, $105,451$. 
(29) Bondybey, V. E.; Räsänen, M.; Lammers, A. Annu. Rep. Prog. Chem. C 1999, 95, 331.

(30) Frisch, M. J.; Trucks, G. W.; Schlegel, H. B.; Scuseria, G. E.; Robb, M. A.; Cheeseman, J. R.; Zakrzewski, V. G.; Montgomery, J. A.; Stratmann, R. E.; Burant, J. C.; Dapprich, S.; Millam, J. M.; Daniels, A. D.; Kudin, K. N.; Strain, M. C.; Farkas, O.; Tomasi, J.; Barone, V.; Cossi, M.; Cammi, M.; Mennucci, B.; Pomelli, C.; Adamo, C.; Clifford, S.; Ochterski, J.; Petersson, G. A.; Ayala, P. Y.; Cui, Q.; Morokuma, K.; Malick, D. K.; Rabuck, A. D.; Raghavachari, K.; Foresman, J. B.; Cioslowski, J.; Ortiz, J. V.; Baboul, A. G.; Stefanov, B. B.; Liu, G.; Liashenko, A.; Piskorz, P.; Komaromi, I.; Gomperts, R.; Martin, R. L.; Fox, D. J.; Keith, T.; Al-Laham, M. A.; Peng, C. Y.; Nanayakkara, A.; Gonzalez, C.; Challacombe, M.; Gill, P. M. W.; Johnson, B. G.; Chen, W.; Wong, M. W.; Andres, J. L.; HeadGordon, M.; Replogle, E. S.; Pople, J. A. Gaussian 98, revision A.9 Gaussian, Inc.: Pittsburgh, PA, 1998.

(31) van Duijneveldt, F. B.; van Duijneveldt-van de Rijdt, J. G. C. M.; van Lenthe, J. H. Chem. Rev. 1994, 94, 1873.

(32) Maçôas, E. M. S.; Khriachtchev, L.; Pettersson, M.; Lundell, J.;

Fausto, R.; Räsänen, M. Vibr. Spectrosc. 2004, 34, 73.

(33) He, H.-Y.; Fang, W.-H. J. Am. Chem. Soc. 2003, 125, 16139.

(34) Su, H.; He, Y.; Kong, F. J. Chem. Phvs. 2000, 113, 1891.

(35) Naik, P. D.; Upadhyaya, H. P.; Kumar, A.; Sapre, A. V.; Mittal, J.

P. Chem. Phvs. Lett. 2001, 340, 116.

(36) Ausloos, P.; Steacie, E. W. R. Can. J. Chem. 1955, 33, 1530

(37) Barnes, A. J.; Hallam, H. E. Trans. Faradav Soc. 1970, 66, 1920.

(38) Dubost, H. Chem. Phvs. 1976, 12, 139.

(39) Abe, H.; Takeo, H.; Yamada, K. M. T. Chem. Phvs. Lett. 1999, $311,153$.

(40) Irvine, M. J.; Mathieson, J. G.; Pullin, A. D. E. Aust. J. Chem. 1982, 35, 1971 .

(41) Khoshkhoo, H.; Nixon, E. Spectrochim. Acta A 1973, 29, 603.
(42) Romano, R. M.; Védova, C. O. D.; Downs, A. J. J. Phvs. Chem. A 2002, 106, 7235 .

(43) Glass, G. P.; Kumaran, S. S.; Michael, J. V. J. Phvs. Chem. 2000, 104,8360 .

(44) Schatte, G.; Willner, H.; Hoge, D.; Knözinger, E.; Schrems, O. J. Phvs. Chem. 1989, 93, 6025 .

(45) Lundell, J.; Räsänen, M. J. Phvs. Chem. 1993, 97, 9657.

(46) Lundell, J.; Räsänen, M. J. Phvs. Chem. 1995, 99, 14301.

(47) Heikkilä, A.; Pettersson, M.; Lundell, J.; Khriachtchev, L.; Räsänen, M. J. Phvs. Chem. A 1999, 103, 2945.

(48) Khriachtchev, L.; Pettersson, M.; Tuominen, S.; Räsänen, M. J. Chem. Phvs. 1997, 107, 7252.

(49) Breda, S.; Lapinski, L.; Reva, I.; Fausto, R. J. Photochem Photobiol. A.: Chem. 2004, 162, 139.

(50) Jiang, G. J.; Person, W. B.; Brown, K. G. J. Chem. Phys. 1975 62,1201 .

(51) Stanton, J. F.; Watts, J. D.; Bartlett, R. J. J. Chem. Phvs. 1991, 94, 404

(52) Cabana, A.; Savitsky, G. B.; Hornig, D. F. J. Chem. Phvs. 1963, 39, 2942.

(53) Galabov, B.; Yamaguchi, Y.; Remington, R. B.; Shaefer, H. F., III. J. Phys. Chem. A 2002, 106, 819.

(54) Wen, Y.; Segall, J.; Dulligan, M.; Witting, C. J. Chem. Phvs. 1994, 101,5665 .

(55) Murto, J.; Ovaska, M. Spectrochim. Acta A 1983, 39, 149.

(56) Latajka, Z.; Ratajczak, H.; Murto, J.; Orville-Thomas, W. J. J. Mol. Struct. 1989, 194, 45

(57) Apkarian, V. A.; Schwentner, N. Chem. Rev. 1999, 99, 1481.

(58) Khriachtchev, L.; Pettersson, M.; Runeberg, N.; Lundell, J.; Räsänen, M. Nature 2000, 406, 874.

(59) Milligan, D. E.; Jacox, M. E. J. Chem. Phys. 1969, 51, 277. 